\title{
1 Influence of run of river dams on floodplain sediments and carbon
}

\section{2 dynamics}

4 Authors:

5 Adam J. Pearson ${ }^{\mathrm{a}, 1}$, James E. Pizzuto ${ }^{\mathrm{a}}$, Rodrigo Vargas ${ }^{\mathrm{b}} *$

6

8 Affiliations:

$9 \quad{ }^{\mathrm{a}}$ Department of Geological Sciences, University of Delaware, Newark, DE 19716, USA

$10{ }^{b}$ Department of Plant and Soil Science, University of Delaware, Newark, DE 19716, USA

11

$12{ }^{1}$ Present address:

13 Department of Earth and Atmospheric Sciences, Saint Louis University, St. Louis, MO, 63108,

14 USA 
Abstract

Quantifying the biophysical impacts of management on river and stream ecosystems is an

22 important issue that requires understanding of ecological, hydrological and geomorphological

23 processes. We conducted a year-long ecogeomorphological experiment to determine

24 sedimentation and carbon cycling differences between run-of-river (ROR) dams in a 200 year

25 old impounded floodplain and a floodplain that was formerly impounded $>65$ years ago. Our

26 study shows that ROR dams do not necessarily enhance floodplain sedimentation or carbon

27 storage, but promote brief periods of sediment $\mathrm{CH}_{4}$ flux (up to $2.91 \mathrm{nmol} \mathrm{CH}_{4} \mathrm{~m}^{-2} \mathrm{~s}^{-1}$ ) to the

28 atmosphere. Removal of a ROR dam may result in channel widening, and removal by lateral

29 transport (i.e., erosion) of nearly $14 \mathrm{MgC}$ per floodplain. We did not find significant differences

30 in mean sediment $\mathrm{CO}_{2}$ fluxes or temperature sensitivity $\left(\mathrm{Q}_{10}=2.1 \pm 0.4\right)$ of $\mathrm{CO}_{2}$ efflux among

31 floodplains. All floodplains were likely an annual net source of sediment $\mathrm{CO}_{2}$ flux (annual mean

32 of $2.12 \pm 0.974 \mu \mathrm{mol} \mathrm{CO} \mathrm{CO}^{-2} \mathrm{~s}^{-1}$ ) to the atmosphere, and a sink for atmospheric $\mathrm{CH}_{4}$ (annual

33 mean of $-0.221 \pm 0.163 \mathrm{nmol} \mathrm{CH}_{4} \mathrm{~m}^{-2} \mathrm{~s}^{-1}$ ). We provide a conceptual model on the management

34 consequences on ROR dam structures for floodplain sedimentation/erosion, and sediment carbon

35 cycling.

37 Keywords: floodplain, sediment respiration, dams, methane, greenhouse gases, stratigraphy, 38 geomorphology 


\section{Introduction}

Large reservoir dams have been shown to be a source of $\mathrm{CH}_{4}$ to the atmosphere

42 (Galy-Lacaux and Delmas, 1997; Rosa et al., 2004; Teodoru et al., 2012), to promote the

43 breakdown of excess nutrients due to long water residence times (Parekh and Mccully, 2004),

44 and to enhance the storage of sediment (Annandale, 2006) and organic matter (Li et al., 2014). In

45 contrast, little information on carbon dynamics and sedimentation of smaller run-of-river (ROR)

46 dams is available. Run-of-river dams may exert a significant influence on landscapes because

47 these structures can be substantially older (one to two centuries) and more numerous (10 to 1)

48 than larger reservoir dams (Csiki and Rhoads, 2010). No studies have been conducted on the

49 impact of ROR dams on the production of greenhouse gas (GHG) fluxes from floodplain

50 sediments, and very few studies have been conducted on the storage of carbon within floodplain

51 sediments (Wang et al., 2014). Recent work on floodplain sedimentation disagrees about the

52 level of anthropogenic enhancement of the storage of sediments within floodplains (Donovan et

53 al., 2015; Hupp et al., 2013; Merritts et al., 2011; Walter and Merritts, 2008). The majority of

54 studies related to ecosystem processes and ROR dams focus on responses to the removal of the

55 dams with little documentation of how existing ROR dams influence carbon dynamics

56 (Gangloff, 2013; Stanley and Doyle, 2003; Tullos et al., 2014). Due to the increasing awareness

57 of ecosystem management on carbon dynamics it is important to properly quantify the effects of

58 ROR dams and their removal across different ecosystems.

59 Floodplains across different ecosystems have been documented as a net source of $\mathrm{CO}_{2}$

60 (Batson et al., 2014; Jacinthe, 2015), a net sink of $\mathrm{CH}_{4}$ to the atmosphere (Jacinthe, 2015; Segers,

61 1998), and have the potential to store carbon (up to $0.22 \mathrm{~kg} \mathrm{C} \mathrm{m}^{-2} \mathrm{yr}^{-1}$ ) in their sediments

62 (DeLaune and White, 2012; Kayranli et al., 2010). Floodplains typically receive sporadic inputs 
63 of sediment and nutrients during overbank floods that further enhance and promote the storage of 64 carbon, production of $\mathrm{CO}_{2}$, and consumption of $\mathrm{CH}_{4}$ (Craft and Casey, 2000; Nanson and Croke,

65 1992; Pizzuto et al., 2008). Studies have shown that the frequency and duration of wetting of

66 floodplains can alter biogeochemical processes (Altor and Mitsch, 2006; Jacinthe et al., 2015;

67 Pacific et al., 2009), and rewetting events substantially influence soil gas fluxes to the

68 atmosphere (Kim et al., 2012). Typically, ROR dams fail to flood the valleys they impound and

69 therefore impounded segments retain a stream-like morphology rather than being converted to a

70 lake (Csiki and Rhoads, 2010; Juracek, 1999). The retention of a fluvial morphology leads to

71 depositional patterns that are similar to a pre-impoundment regime, including bedload stored

72 within the channel and overbank sediments deposited on the floodplain. Furthermore, the water

73 table upstream of the ROR dams is kept artificially elevated potentially creating anoxic

74 conditions influencing the biogeochemistry of floodplain sediments.

75 Dam removal has increasingly become an ecological tool for the restoration of rivers in

76 recent decades (Csiki and Rhoads, 2010; Stanley and Doyle, 2003); however, the consequences

77 of removing a dam from a stream are varied and depend on the regional setting (Doyle et al.,

78 2003b; Pizzuto, 2002; Skalak et al., 2011). Generally, a stream will incise into stored sediment in

79 the channel, perhaps even initiating a knick point, (Sawaske and Freyberg, 2012) and eventually

80 the stream will widen to some degree into the banks of the channel (Major et al., 2012; Pearson

81 et al., 2011; Sawaske and Freyberg, 2012). Later, the stream finally adopts a form that is quasi-

82 stable under the post-removal flow and sediment regime. The extent and timing of incision and

83 widening is poorly constrained and is currently being actively debated (Donovan et al., 2015;

84 Hupp et al., 2013; Merritts et al., 2011; Walter and Merritts, 2008). 
The goal of this study is to document the ecogeomorphological differences between pairs

86 of floodplains on the same river that have experienced similar land use, are located within the

87 same climatic region, and generally have a similar vegetation pattern. The key difference

88 between these two pairs of floodplains is that the first pair has a 200 year old impounded

89 floodplain and the second pair has a floodplain that was initially impounded 200 years ago but

90 was breached at least 65 years ago. We show how the resulting geomorphological differences

91 influence ecosystem processes (e.g., GHG fluxes and carbon storage). We propose two main

92 hypotheses. The first is related to the geomorphology and stratigraphy of floodplains: H1- ROR

93 dams increase sedimentation upstream of the dam and facilitate thicker floodplain sequences

94 than would otherwise be present, and the removal of a dam without replacement over the long

95 term allows some but not all of the accumulated sediment to be eroded. The second hypothesis is

96 related to the ecosystem processes and is split into two parts. The first part deals with the long-

97 term impacts (i.e., decadal): H2a- impounded floodplains store more carbon than non-impounded

98 floodplains. The second part deals with current processes (i.e., <1 year): H2b - impounded

99 floodplains are a source of methane $\left(\mathrm{CH}_{4}\right)$ likely due to flooding and anoxic conditions, whereas

100 all other floodplains are a sink for $\mathrm{CH}_{4}$; removed-dam floodplains are a larger source of carbon

101 dioxide $\left(\mathrm{CO}_{2}\right)$ compared to other floodplains, likely as a result of higher rates of organic matter

102 decomposition that could have been accumulated during the impounded period. We test these

103 hypotheses by describing the geomorphology and stratigraphy of floodplains and through

104 measurements of sediment GHG fluxes, sediment temperature, sediment moisture, sediment

105 carbon and nitrogen, and biomass accumulation in paired floodplains.

106

107 2. Materials and methods 
The study area is located in northeastern United States, in northern Delaware (Fig. 1)

109 within the Red Clay Creek $\left(140 \mathrm{~km}^{2}\right)$ watershed, a tributary to the Christina River and ultimately

110 the Delaware River estuary. The study sites are located along an alluvial-bedrock channel

111 (Howard, 1998; Turowski et al., 2008) with mixed sand and gravel bed material and frequent

112 pools and riffles, well-developed narrow floodplains, cohesive silty banks (Jacobson and

113 Coleman, 1986; Walter and Merritts, 2008), and temperate forested riparian zones. Our study

114 area within the Christina River basin lies just north of the Fall Line (Renner, 1927) within the

115 Piedmont physiographic province (Fischer et al., 2004). The Christina River basin has 7.8\%

116 impervious surfaces and a population density of 1764 per $\mathrm{km}^{2}$. The basin is $30 \%$ developed, $32 \%$

117 forested, and 37\% agricultural (Kauffman et al., 2008). The underlying bedrock consists of

118 Cambrian metamorphic rocks of the Wissahickon Formation (Schenck et al., 2000) and

119 Ordovician metamorphic rocks of the Faulkland gneiss and Windy Hill gneiss (Schenck et al.,

120 2000). Intense precipitation events are usually delivered by thunderstorms, hurricanes or

121 nor'easters. The mean annual precipitation in the watershed is $115.56 \mathrm{~cm}$ year $^{-1}$ with a mean

122 annual temperature of $12.7^{\circ} \mathrm{C}$.

123 The Christina River basin experienced massive deforestation during colonial times as

124 forests were clear-cut for agriculture. Construction of ROR dams began as early as 1802 when

125 the DuPont family settled in the area (Kauffman et al., 2008). At the height of ROR dam

126 construction, there may have been hundreds of operating ROR dams in the watershed (Walter

127 and Merritts, 2008), but only 72 ROR dams are currently in place in the subwatersheds of the

128 Christina River, Brandywine River, White Clay Creek, Red Clay Creek and Naamans Creek

129 (Kauffman et al., 2008). 
We focus on two ROR dams, the Barley Mill Road (BMR) dam and the former Fell Spice

131 Mill (FSM) dam. These dams are located within $3 \mathrm{~km}$ from each other so they are subject to

132 similar climatic variability and mean annual temperature $\left(23.1^{\circ} \mathrm{C}\right)$ and total annual precipitation

133 (84.4 cm). The BMR dam is still in place, located along Barley Mill Road (Fig. 1) and featured

134 an old slitting and rolling mill (i.e. a mill for processing iron rods) that was in operation from

135 1814-1918 (Delaware Department of Transportation, 2003). Following its active use, the BMR

136 dam was stabilized with concrete and it remains intact. The FSM dam featured a spice mill that

137 started operation in 1828 and failed sometime before 1950 along with the dam. The former

138 location of the FSM dam is upstream of where Faulkland Road crosses the Red Clay Creek (Fig. $1391)$.

140 The floodplain vegetation at the BMR site differs between the upstream impounded 141 floodplain and the downstream non-impounded floodplain. The BMR upstream floodplain 142 vegetation is dominated by grasses and nettles with few tall trees. The BMR downstream 143 floodplain vegetation is dominated by bushes and tall trees. The FSM floodplains have similar

144 woody bush and tall trees on both the upstream formerly impoundment floodplain and 145 downstream non-impounded floodplain.

147 2.1. Sampling design

148 The data collected allowed us to look at both the long-term (i.e., decadal) impacts and 149 current short-term (i.e., <1 year) responses of dam building and removal. Long-term impacts 150 were assumed to be recorded within the sediment column of the floodplains such as the amount 151 of carbon and nitrogen stored at depth, and geomorphological information connected to dam 
152 building. Short-term responses were measured bi-weekly and include sediment GHG fluxes,

153 sediment moisture, sediment temperature, and biomass collections.

154 Our field measurements focused on the floodplains immediately upstream and

155 downstream of each ROR dam (former in the case of FSM). We established three cross sections

156 per floodplain (total of 12 cross sections) perpendicular to the flow of the stream. Cross sections

157 were subdivided into three distinct zones based on distance from the channel. The near

158 floodplain was the zone of the floodplain immediately adjacent to the channel. The far floodplain

159 was the zone of the floodplain furthest from the channel before the toe of the hillslope. The

160 middle floodplain was the zone between the near and far floodplain. A single location for

161 sampling was located along each cross section within each of the three zones (36 sampling

162 locations). Sampling locations served as the sites for a suite of measurements designed to

163 characterize the impact of ROR dams on floodplain carbon dynamics.

\subsection{Measurements of long-term impacts}

166 Coring at sampling locations was performed with a 1-1/2' gouge auger that was driven

167 until refusal (defined as the point to which the coring device cannot be driven any further,

168 typically as a result of encountering large rocks, a gravel layer, or extremely dense sediment).

169 Core descriptions were logged in the field and samples were taken for sediment bulk density,

170 total carbon, and total nitrogen from different compositional layers in each core. Stratigraphy

171 down core was assessed by compositional variations and color was determined with a Munsel

172 Color Chart. We used five compositional categories based on grain size estimated from cores

173 (using grain-size terminology of the Wentworth scale; Wentworth, 1922). The term gravel

174 applies to a layer with $>50 \%$ gravel or indicates refusal on rocks and gravel. The term sand 
175 applies to a layer with $90-100 \%$ sand and 0-10\% mud. The term muddy sand applies to a layer 176 with $60-80 \%$ sand and $20-40 \%$ mud. The term sandy mud applies to a layer with $20-40 \%$ sand 177 and 60-80\% mud. Lastly, the term mud applies to a layer with 0-10\% sand and 90-100\% mud.

178 For the purposes of our grain size categories, mud includes both the silt and clay fraction as they 179 cannot be distinguished in the field. Apart from compositional categories extensive mottling at 180 depth was also identified in the field as a distinct characteristic. We assume that extensively 181 mottled layers may mark potentially persistent water table elevations at depth. Sediment samples 182 were dried in an oven at $45^{\circ} \mathrm{C}$ and analyzed for bulk density before being processed for total 183 carbon and total nitrogen using a CHNS Elemental analyzer (vario MICRO cube, Elementar 184 Americas Inc., Mt. Laurel, NJ). We calculated total carbon down core by first using measured 185 representative bulk density to convert volumes of the core to mass based on the depth intervals of 186 the bulk density measurements. The down core volumes were then multiplied by the measured 187 percent carbon. The average of nine cores was use to give a mean total mass of carbon stored at 188 depth per floodplain.

189 Topographic cross sections were surveyed with a total station or constructed using a 190 combination of Trimble GeoXH to ascertain location and topographic map data provided by 191 New Castle County (2-foot (i.e., $0.61 \mathrm{~m}$ ) contour interval; State of Delaware, 2008) to determine 192 elevation. Cross sections were used to correlate coring data within cross sections in addition to 193 determining depth of floodplains. Recent aerial photography was also used to calculate an 194 average width of each section of stream, upstream and downstream of the dam, to try and 195 determine if the removal of the FSM had any influence on width adjustment over time. The 196 average widths of stream sections were determined by taking the perimeter of the active stream 197 channel and dividing by the length of the stream section. Trimble surveys were conducted during 
198 the months where trees had no leaves (November 2014 and April 2015) and the Trimble

199 TerraSync software (Trimble, Sunnyvale, CA) was used to download the data and provide an

200 estimate of the error.

201

202

\subsection{Measurements of short-term responses}

203 Litter biomass from the soil O-horizon was sampled at all 36 sampling locations (Fig. 1)

204 during the beginning (May), peak (August), and end (October) of the 2014 growing season. The

205 entire O-horizon was collected from within a $0.30 \mathrm{~m} \times 0.30 \mathrm{~m}$ area, oven dried at $45^{\circ} \mathrm{C}$ for 72

206 hours, and then weighed in order to calculate the dry mass (i.e., litter biomass in $\mathrm{g} \mathrm{m}^{-2}$ ).

207 Superficial (10 cm depth) sediment samples were collected using a $2.5 \mathrm{~cm}$ push core to measure $208 \mathrm{pH}$ (HI 99121; Hanna Instruments) at the same time as the O-horizon collection.

209 Sediment GHG fluxes (i.e., $\mathrm{CO}_{2}$ and $\mathrm{CH}_{4}$ fluxes) were measured every two weeks using 210 an Ultraportable Los Gatos Greenhouse Gas Analyzer (Los Gatos Research, Santa Clara, CA), 211 hereafter LGR. This instrument can measure $\mathrm{CH}_{4}$ concentrations from 0.01 to $100 \mathrm{ppm} \pm 0.002$

212 ppm at 1 Hertz. In addition, the LGR can measure $\mathrm{CO}_{2}$ concentrations from 1 to $20000 \pm 0.3$

213 ppm at 1 Hertz. A $15 \mathrm{~cm}$ diameter PVC collar was permanently installed at each sampling

214 location at $5 \mathrm{~cm}$ depth 14 days before measurements started (36 total collars, 9 per floodplain).

215 We measured GHG fluxes using a closed system where the vacuum pump of the LGR was 216 attached to a chamber that allowed gases to accumulate for 3 minutes to record ( 2 second

217 response) the change in concentration within the chamber. Therefore, the GHG flux at each

218 sampling location was calculated using 180 measurements and fitting the following equation

219 (Pumpanen et al., 2004): 


$$
f C x=\left(\frac{d C}{d t}\right)\left(\frac{V_{c}}{A_{c}}\right) \frac{P}{\left(R *\left(T_{s}+273.15\right)\right)}
$$

221 where $f C x$ is the efflux of a GHG $\left(\mathrm{CO}_{2}\right.$ or $\left.\mathrm{CH}_{4}\right), d C / d t$ is the change in concentration with time

222 measured by the LGR $\left(\mathrm{ppm} \mathrm{s}^{-1}\right), V_{c}$ is the system volume (i.e., LGR + soil chamber; $0.01795 \mathrm{~m}^{3}$ ),

$223 A_{c}$ is the area of the chamber $\left(0.018 \mathrm{~m}^{2}\right), \mathrm{P}$ is atmospheric pressure $\left(101.325 \mathrm{~kg} \mathrm{~m} \mathrm{~s}^{-2}\right), R$ is the

224 ideal gas law constant $\left(0.00831447 \mathrm{~kg} \mathrm{~m}^{2} / \mu \mathrm{mol} \mathrm{K} \mathrm{s}^{2}\right), T_{s}$ is the measured sediment temperature

$225\left({ }^{\circ} \mathrm{C}\right)$, and 273.15 is the conversion to degrees Kelvin. In addition to biweekly measurements of $T_{s}$

226 we measured sediment moisture at $5 \mathrm{~cm}$ depth (WET-2, Delta-T Devices, Cambridge, UK). We

227 report sediment gas fluxes for both $\mathrm{CO}_{2}\left(\mu \mathrm{mol} \mathrm{m} \mathrm{m}^{-2}\right)$ and $\mathrm{CH}_{4}\left(\mathrm{nmol} \mathrm{m}^{-2} \mathrm{~s}^{-1}\right)$ as a monthly

228 average of the bi-weekly measurements for each sampling location.

230 using an exponential equation:

$$
f C x=\beta^{*} \mathrm{e}^{\left(\alpha^{*} \mathrm{Ts}\right)}
$$

232 where $f C x$ is the efflux of a GHG $\left(\mathrm{CO}_{2}\right.$ or $\left.\mathrm{CH}_{4}\right), \beta$ and $\alpha$ are regression coefficients, and $\mathrm{T}_{\mathrm{s}}$ is the 233 sediment temperature. The temperature sensitivity $\left(\mathrm{Q}_{10}\right)$ and its $95 \%$ confidence intervals $(\mathrm{CI})$ 234 were calculated using:

$$
\mathrm{Q}_{10}=\mathrm{e}^{10^{* \alpha} \alpha}
$$

236 where $\alpha$ is the regression coefficient obtained from equation (2). The 95\% CI were calculated

237 using the upper and lower 95\%CI of $\alpha$ derived from equation (2). Similar approaches to calculate $23895 \% \mathrm{CI}$ for $\mathrm{Q}_{10}$ values have been reported previously (Vargas et al., 2012).

240 Gaging station 01480000 Wooddale at Red Clay Creek (Fig. 1), and precipitation data during the 241 entire study period was acquired from the Mt. Cuba weather station in Hockessin, DE (Fig. 1). 
242 Data were analyzed using a repeated ANOVA using time and sampling location as fixed factors.

243 If significant differences were found $(\alpha=0.5)$ then a Tukey-Kramer post hoc test was applied to

244 identify differences among the treatments.

246 3. Results

247 3.1. Geomorphological surveys and sediment cores

248 3.1.1. Stratigraphy

249 Floodplain cores show that both downstream floodplains at BMR and FSM have a similar 250 stratigraphic sequence. The near floodplain locations are predominantly sand and far floodplain 251 locations are primarily mud (Figs. S1 and S2). The middle floodplain locations are a mixture of 252 sand and mud, typically alternating between muddy sand and sandy mud. Both downstream 253 floodplains also have a distinct mottled layer before refusal (Figs. S1 and S2). Refusal in the 254 downstream locations was predominantly a gravel layer (Figs. S1 and S2).

255 The floodplain upstream of the BMR dam has a large amount of sand at the surface of the 256 near floodplain locations (Fig. S3) with mud content increasing towards the far floodplains. The 257 middle floodplains generally consist of muddy sand and sandy mud and the far floodplains 258 generally transition to mud. The near floodplain at depth transitions from sand to muddy sand 259 before refusing on gravel (Fig. S3). At depth the middle floodplain is a complex interfingering of 260 sandy muds and muddy sands that refuse on gravels (Fig. S3). The far floodplain is typically 261 mud or sandy mud and refusing on gravel (Fig. S3). There are two layers of mottling, 1) about 1 $262 \mathrm{~m}$ depth in the middle and 2) directly above refusal, which is approximately $2.5-3 \mathrm{~m}$ deep (Fig. 263 S3). 
The floodplain upstream of the former FSM dam lacks the large sandy levee deposits at

265 the near floodplains and instead has interbedded layers of sandy mud and muddy sand to refusal

266 which is a gravel layer (Fig. S4). Both the middle floodplains and far floodplains are capped with

267 mud layers that are underlain by sandy mud, typically mottled. Finally, refusal at the middle and

268 far floodplains is a mud layer that is too dense to core through (Fig. S4).

270 3.1.2. Floodplain depths and stream widths

271 The geomorphic cross sections in conjunction with the sediment cores show that the

272 average depth of the upstream BMR floodplains is thicker than the three other floodplains

273 studied with an average depth of $210 \mathrm{~cm}$ (Table 1); however, the upstream floodplains are not

274 substantially thicker than their downstream counterparts. Aerial photography shows that the

275 upstream and downstream average stream width of the BMR site is 23.2 and $23.1 \mathrm{~m}$ respectively,

276 whereas the upstream and downstream average stream width of the FSM site is 23.9 and $20.0 \mathrm{~m}$

277 respectively. Given the similar widths upstream and downstream of the BMR dam, the lack of

278 similarity between the upstream and downstream FSM dam may represent an approximate

279 widening of $\sim 4 \mathrm{~m}$.

280

281 3.1.3. Sediment properties, total carbon, and total nitrogen

282 The $\mathrm{pH}$ of the sediment at the upstream floodplain of BMR was $6.12( \pm 0.33)$, the

283 downstream floodplain at BMR was $6.28( \pm 0.28)$, the upstream floodplain at FSM was 5.50

$284( \pm 0.37)$, and the downstream floodplain at FSM was $6.28( \pm 0.28)$. There was no statistical

285 difference between the $\mathrm{pH}$ of upstream and downstream floodplains at BMR; however there was 
286 a statistical difference between the $\mathrm{pH}$ of upstream and downstream floodplains at FSM

287 (ANOVA, $\mathrm{F}=49.76, \mathrm{p}<0.001)$.

288 Sediment cores show that the floodplains at BMR store more carbon and nitrogen with

289 depth than the floodplains at FSM (ANOVA, F = 12.52, $\mathrm{p}=0.001$; based on Tukey-Kramer test),

290 but there is no statistical difference between the upstream and downstream floodplains at BMR

291 nor the upstream and downstream floodplains at FSM (Figs. 2 and 3). The total carbon stored in

292 an average cross section in each floodplain is $80 \pm 41 \mathrm{MgC}$ for the upstream BMR, $58 \pm 8.4 \mathrm{MgC}$

293 for the downstream BMR, 66 $\pm 40 \mathrm{MgC}$ for the upstream FSM, and $17 \pm 6.8 \mathrm{MgC}$ for the

294 downstream FSM (Table 1; Table S1-S5).

295

296 3.2. Hydrologic data

297 The climatological data acquired from the USGS gaging station at Wooddale

298 (014008000) and the Mt. Cuba Weather station (Fig. 1) are shown in Fig. 4. The large peak in

299 both discharge and precipitation occurred on the night of April 30, 2014 and is the fifth largest

300 flood recorded at Wooddale and corresponds to a 15 year flood based on the Log-Pearson III

301 analysis (Pearson and Pizzuto, 2015). The discharge event flooded three of the four floodplains

302 in our study and removed three of the gas chamber collars during the event, which were later

303 replaced. The absence of newly deposited sediment and the undisturbed leaf litter at the upstream

304 floodplain of the FSM site suggest that the river did not flood this area.

305

306 3.3. Sediment $G H G$ fluxes

307 3.3.1. Temporal variations in GHG fluxes 
The overall mean of sediment $\mathrm{CO}_{2}$ flux across floodplains is $2.12 \pm 0.97 \mu \mathrm{mol} \mathrm{CO} \mathrm{Cm}^{-2} \mathrm{~s}^{-}$

$309{ }^{1}$. The sediment $\mathrm{CO}_{2}$ flux exhibits a similar temporal pattern among three of the four floodplains

310 (BMR upstream, BMR downstream, and FSM downstream), starting at or near zero $\mu$ mol $\mathrm{CO}_{2}$

$311 \mathrm{~m}^{-2} \mathrm{~s}^{-1}$ for the month of April, increasing towards peak output in June (4.13-4.55 $\mu \mathrm{mol} \mathrm{CO}_{2} \mathrm{~m}^{-2} \mathrm{~s}^{-}$

$312^{1}$ ) before leveling off through July and August (3.09-4.09 $\left.\mu \mathrm{mol} \mathrm{CO}_{2} \mathrm{~m}^{-2} \mathrm{~s}^{-1}\right)$, steadily decreasing

313 towards zero over September and October, and finally reaching zero or near it in November. The

314 FSM upstream floodplain exhibited a slightly different $\mathrm{CO}_{2}$ flux trend, with an increasing rate of

315 efflux until September before falling towards zero similar to the other three floodplains. The

316 FSM floodplains have lower variability of $\mathrm{CO}_{2}$ flux across all months of sampling than the BMR

317 floodplains, with the FSM upstream floodplain having the lowest (i.e., coefficient of variation;

$318 \mathrm{CV}=0.52$; Fig 5). The downstream BMR floodplain has the greatest variability among the four

319 floodplains (CV = 0.78; Fig. 5).

320 The overall mean of sediment $\mathrm{CH}_{4}$ flux across floodplains is $-0.22 \pm 0.16 \mathrm{nmol} \mathrm{CH}_{4} \mathrm{~m}^{-2}$

$321 \mathrm{~s}^{-1}$ however, the $\mathrm{CH}_{4}$ flux patterns differ between BMR and FSM floodplains. Both FSM

322 floodplains act as sinks the entire eight months and exhibit very similar rates (Fig. 5). Both BMR

323 floodplains exhibit a spike in $\mathrm{CH}_{4}$ flux up to $2.91 \mathrm{nmol} \mathrm{CH}_{4} \mathrm{~m}^{-2} \mathrm{~s}^{-1}$ (Fig. 5) during the month of

324 May, and elevated $\mathrm{CH}_{4}$ flux continued into the month of June for the upstream BMR floodplain

325 before both floodplains became sinks for $\mathrm{CH}_{4}$ once more (Fig 5). Once again the FSM

326 floodplains exhibit the lower variability across the sampling period, however, the downstream

327 FSM floodplain has the lowest variability (i.e., coefficient of variation) with regards to $\mathrm{CH}_{4}$ flux

$328\left(\mathrm{CV}=0.68\right.$; Fig 5). The upstream BMR floodplain has the largest $\mathrm{CH}_{4}$ flux $(\mathrm{CV}=3.8$; Fig 5).

329 The sediment temperature and sediment moisture among all four floodplains exhibits

330 nearly the same pattern during the eight-month study, decreasing across the study period. 
331 Sediment temperature and moisture have similar values and temporal trends across all four

332 floodplains (Fig. 5).

334 3.3.2. Relationship between sediment GHG fluxes and floodplain sampling location

335 Upstream of the BMR Dam the sediment $\mathrm{CO}_{2}$ flux is highest near the stream (ANOVA, F

$336=10.25, \mathrm{p}<0.001$, based on Tukey-Kramer test) and has similar magnitude in the middle and far

337 floodplains (Fig. 5). Downstream of former FSM Dam the far floodplain has the highest

338 sediment $\mathrm{CO}_{2}$ flux (ANOVA, $\mathrm{F}=9.77$, $\mathrm{p}<0.001$; based on Tukey-Kramer test) with the near

339 and middle floodplains having similar magnitudes (Fig. 5). The sediment $\mathrm{CO}_{2}$ flux is not

340 statistically different among all floodplain locations both downstream of BMR Dam and

341 upstream of the former FSM Dam (Fig. 5).

342 The far floodplain both upstream and downstream of BMR Dam seems to be different

343 with respect to $\mathrm{CH}_{4}$ flux than the near and middle floodplains (Fig. 5); however, only the

344 upstream far floodplain of BMR Dam sediment $\mathrm{CH}_{4}$ flux is statistically different from the

345 upstream BMR near and middle floodplain locations (ANOVA, F = 11.13, p < 0.001; based on

346 Tukey-Kramer test). All locations of both floodplains of the former FSM Dam are sinks of $\mathrm{CH}_{4}$

347 and are not statistically different from each other (Fig. 5).

348 Sediment temperatures among all sections of all floodplains are statistically similar (Fig.

349 5). Far floodplains are generally the wettest sections of the floodplains and the near floodplains

350 are the driest (Fig. 5). Spatial differences in sediment moisture on the upstream floodplain of the

351 former FSM Dam are not statistically different.

352

353 3.3.3. Relationship between GHG and sediment moisture and sediment temperature 
The sediment temperature at both sites was positively correlated with sediment flux of

$355 \mathrm{CO}_{2}$ with an exponential fit $\mathrm{y}=0.45 * \mathrm{e}^{0.074 \mathrm{x}}$ and $\mathrm{y}=0.41 * \mathrm{e}^{0.084 \mathrm{x}}$ and an $\mathrm{r}^{2}$ value of 0.69 and 0.83

356 for the BMR site and FSM site respectively (Fig. 6). The BMR site has a $\mathrm{Q}_{10}$ of $2.10 \pm 0.6(95 \%$

$357 \mathrm{CI})$ and the $\mathrm{FSM}$ site has a $\mathrm{Q}_{10}$ of $2.31 \pm 0.7$ (95\% CI), so no differences were found in $\mathrm{Q}_{10}$

358 between sites. Sediment temperature had no correlation with $\mathrm{CH}_{4}$ flux, and sediment moisture at

359 both sites had no correlation with $\mathrm{CO}_{2}$ flux (Fig. 6). Sediment moisture was linearly correlated

360 with $\mathrm{CH}_{4}$ flux with an $\mathrm{r}^{2}$ value of 0.43 and 0.38 for the BMR site and FSM site, respectively

361 (Fig. 6). Significant trends are reported for p-values $<0.05$.

\subsection{Soil O-horizon biomass data}

The overall averaged biomass of the upstream floodplain at the BMR site had an

365 increasing trend over the course of the monitoring experiment (Fig. 7), while the overall

366 averaged biomass of the downstream floodplain at the BMR site decreased towards the middle of

367 the experiment and ended with more biomass than it started the experiment with (Fig. 7). The

368 averaged biomass of the upstream floodplain at FSM site remained relatively constant the entire

369 experiment (Fig. 7), while the downstream floodplain at FSM had a large increase towards the

370 middle of the experiment and decreased towards the end (Fig. 7). Biomass data are averaged for

371 each collection period and reported with a $95 \% \mathrm{CI}$.

\section{4. Discussion}

Dam building and dam removal alters adjacent floodplain morphology, which in turn

375 modifies long- and short-term ecosystem processes. We estimate, based on our geomorphic 376 survey data and aerial photographic analysis, that the removal of the FSM Dam may have caused 
377 erosion of previously stored material up to at most $2800 \mathrm{~m}^{3}$. We base this estimate on the 378 average depth of the upstream FSM floodplains $(\sim 1.4 \mathrm{~m})$, an average length of impounded

379 floodplain $(1000 \mathrm{~m})$, and a conservative estimate of widening due to the removal of the FSM

380 dam ( 2 m). Assuming that the estimated material lost with dam removal is $2800 \mathrm{~m}^{3}$, then based

381 on the carbon present currently within the floodplain the removal of the dam may have resulted

382 in a carbon loss of nearly $14 \mathrm{Mg} \mathrm{C}$. Sediment cores show that downstream floodplains from both

383 sites exhibit similar depositional patterns of mostly sand near the channel, mostly mud far from

384 the channel and a mixing in the middle part of the floodplain. The upstream BMR floodplain

385 exhibits a more even distribution, both vertically and horizontally, of sand throughout the

386 floodplain. Lastly, sediment GHG flux measurements show that all floodplains are a source of

$387 \mathrm{CO}_{2}$ to the atmosphere, act as sinks for $\mathrm{CH}_{4}$, and an impounded floodplain is capable of

388 becoming a sporadic source of $\mathrm{CH}_{4}$ to the atmosphere for at least for up to two months following 389 a flood event.

\subsection{Sediment storage and floodplain carbon}

392 Floodplains upstream of the dams in our study do not statistically store more sediment

393 than the downstream floodplains similar to the work of Hupp et al. (2013). This is contrary to our

394 initial hypothesis and the work of others (Merritts et al., 2011; Schenk and Hupp, 2009; Walter

395 and Merritts, 2008). Despite the lack of more sediment, run-of-river (ROR) dams do seem to

396 increase the amount of sand present in the floodplains upstream of dams both laterally and

397 vertically as evidenced by the large levee deposits at the near floodplain location and the

398 presence of sand in the far floodplain location of the BMR site. In contrast, the downstream 
floodplains typically have mostly sand in the near floodplains in a typical levee deposit, a mix of

400 sand and mud in the middle floodplains, and mostly mud in the far floodplains.

401 Removal or breaching of a ROR dam may be followed by channel widening into

402 floodplain deposits. The formerly impounded upstream floodplain at FSM lacks characteristic

403 levee deposits that are present at the BMR site. The high level of sand content typically stored

404 near the channel may have provided easily erodible material. The upstream section at FSM is $\sim 4$

$405 \mathrm{~m}$ wider than its downstream counterpart suggesting that the stream may have experienced

406 widening after the removal of the dam. Assuming that the upstream floodplain at FSM once had

407 a similar level of stored carbon per cross section as the upstream floodplain at BMR currently

408 stores, then the widening after removal of the dam has transported nearly $14 \mathrm{MgC}$ laterally

409 through erosion processes. Widening is a common occurrence after a dam removal (Doyle et al.,

410 2003a; Pizzuto, 2002; Sawaske and Freyberg, 2012).The combination of widening and lowered

411 stream level caused by dam removal has kept the upstream portion of the stream from

412 overtopping its banks. This is evidenced by the lack of disturbance to the floodplain surface

413 following the April 2014 flood, which was a 15 year event for the watershed and was the fifth

414 largest flow since 1943. The widening of the stream after removal has also likely removed what

415 would have been the FSM near floodplain and instead the middle floodplain is currently closest 416 to the channel.

417 Floodplains upstream of dams do not store more total carbon and total nitrogen per $\mathrm{m}^{2}$

418 than downstream floodplains, similar to sediment storage. Statistically the pair of BMR

419 floodplains store more carbon and nitrogen than the pair of FSM floodplains; however, there is

420 no statistical difference between the upstream (impounded) and downstream (non-impounded)

421 floodplains at either the BMR or the FSM. The formerly impounded floodplains do not maintain 
422 their storage of carbon and nitrogen as the stream erodes into previously stored materials so the

423 net loss of carbon is due to lateral movements due to erosion processes. Furthermore, we

424 postulate that the drop in water table could expose labile carbon that could be rapidly

425 decomposed by microbial metabolism (Fontaine et al., 2004; Qiao et al., 2014) resulting in larger

426 carbon losses during the first years after ROR dam removal.

\subsection{Sediment temperature and sediment moisture}

The presence, absence or removal of ROR dams has no effect on surface sediment

430 temperature, likely because vegetation cover was similar between sites and the high water

431 content in sediments of the floodplains that acted as a temperature buffer.

432 Surface sediment moisture data shows that ROR dams enhance the floodplain soil

433 moisture levels and maintain higher levels of sediment moisture than downstream floodplains. In

434 stark contrast, the near floodplain location of all four floodplains always had low levels of

435 sediment moisture due to the high levels of sand. The BMR upstream floodplain, predominately

436 the far floodplain, was kept fully inundated for the entire month of May and parts of June after

437 the April 2014 flood, a phenomenon not repeated at any other floodplain location. The increased

438 stream level upstream of the dam prevents the floodplains from drying out as rapidly as would be

439 expected for Mid-Atlantic floodplains (Batson et al., 2014) and has substantial influence on the

440 dynamics of GHG efflux (Bodelier et al., 2012; Kayranli et al., 2010; Whalen, 2005).

442 4.3. Sediment $\mathrm{CO}_{2}$ fluxes

443 All floodplains in our study, regardless of relationship to ROR dams, have similar

444 sediment $\mathrm{CO}_{2}$ flux rates, contrary to our hypothesis (Fig.5). We had expected the formerly 
445 impounded upstream floodplain at FSM to be the largest source of $\mathrm{CO}_{2}$ flux to the atmosphere 446 due to the availability of previously stored carbon. We postulate that during initial dewatering 447 after dam breaching the FSM floodplain became a large source of $\mathrm{CO}_{2}$ when much of the stored 448 carbon was accessible, and afterwards the levels of $\mathrm{CO}_{2}$ production returned to normal once the 449 liable carbon had been consumed. As it has been at least six decades since the FSM was in place 450 it is likely that any stored carbon from previous damming had been consumed in this time.

451 Changes in temperature dependency (i.e., $\mathrm{Q}_{10}$ ) cannot explain the temporal differences in 452 sediment $\mathrm{CO}_{2}$ flux between sites, but differences could be the result of several factors. First, 453 there are slightly differences in the first constant $(\beta)$ of equation 2 , which could be interpreted as 454 basal respiration. Second, we postulate that spatial heterogeneity (i.e., represented by the CV) 455 should be considered as previous studies have shown important "hot spots" in soil $\mathrm{CO}_{2}$ flux that 456 can influence the overall mean, the temporal trends, and the annual sums (Leon et al., 2014). The 457 upstream floodplain of FSM did have the lowest variability of all floodplains likely due to the 458 fact that it can no longer be flooded easily because the stream has widened into the stored 459 floodplain sediments and is 2-3 m lower than the top of the bank. This leads to the only inputs 460 into the system from leaf litter and the atmosphere, whereas all other floodplains have higher 461 variability, likely due to flooding bringing in an influx of dissolved organic matter and solid 462 organic matter along with leaf litter and atmospheric deposition. Therefore, continuous 463 measurements and longer records are needed to fully capture the temporal dynamics of sediment $464 \mathrm{CO}_{2}$ dynamics (Vargas et al., 2011).

465 
Our hypothesis regarding $\mathrm{CH}_{4}$ flux was partially confirmed as currently impounded

468 floodplains source $\mathrm{CH}_{4}$ when they become inundated as the upstream floodplain at BMR did

469 after the flood of April 2014. We also found that downstream floodplains experience a spike of

$470 \mathrm{CH}_{4}$ flux when inundated; however, only impounded floodplains were statistically a source of

$471 \mathrm{CH}_{4}$ flux. Additionally, the impounding promoted a longer $\mathrm{CH}_{4}$ spike because the ROR dam

472 keeps the water table artificially higher than it would normally be and maintains a higher level of

473 floodplain saturation. It is widely known that extended periods of high levels of sediment

474 moisture allows sediment biogeochemistry to switch from an aerobic dominated regime to an

475 anaerobic dominated one increasing $\mathrm{CH}_{4}$ production (Segers, 1998). Yet despite the extended

476 saturation, all floodplains in our study are net sinks for $\mathrm{CH}_{4}$ when averaged over the entire study

477 period with similar fluxes reported for temperate forest ecosystems (Bodelier et al., 2012)

\subsection{Conceptual model of run-of-river dam influence on floodplain construction and carbon}

$480 \quad$ cycling

Combining our geomorphologic and stratigraphic data with our biogeochemical

482 measurements we propose a conceptual model for the influence of ROR dams on floodplain 483 sedimentation and carbon cycling (Fig. 8). Our conceptual model attempts to demonstrate the

484 influence of a ROR dam based on stages of a dam's life span. Initially, after a ROR dam is first

485 built, some portions of the upstream floodplain are continuously flooded. Sediment and organic

486 matter begins to accumulate rapidly as the upstream floodplain accretes based on the newly

487 elevated water level upstream of the dam. The floodplain downstream of the dam is likely cut off

488 from the upstream sediment supply for some amount of time and sediment inputs to the

489 downstream floodplain are likely lessened (Fig. 8a). 
Next, the upstream flood plain is no longer continuously flooded anywhere; however, the 491 upstream floodplain continues to accumulate sediment as overbank accretion is easier to achieve 492 in a dammed state. Sediment transport over the dam has likely restored input of sediment to the 493 downstream floodplain (Pearson and Pizzuto, 2015). Sediment and organic matter are added to 494 both upstream and downstream floodplains at similar rates (Fig. 8b).

495 For the purposes of our conceptual model, there exist two options that can befall a dam: it 496 can continue to exist (Fig. 8c) or it can be removed/breached (Fig. 8d). In the case of continued 497 damming (Fig. 8c) the upstream floodplain continues to receive sediment and organic matter as 498 the floodplain is able to accrete further. The water table is kept artificially elevated in the 499 upstream floodplain.

500 In the case of removal/breaching (Fig. 8d), the stream level upstream of the former dam 501 falls back to near a pre-dam level, and begins to rework part of the formerly impounded 502 floodplain, likely eroding the highly sandy deposits immediately adjacent to the stream. The 503 downstream floodplain may receive a large influx of sediment but this pulse is typically 504 transitional and short lived (Pearson et al., 2011). Based on the difference between the bank 505 height and stream level upstream of the former dam, streams may not be able to overtop their 506 banks during flood events as easily as they could during damming. This will decrease stream 507 based inputs to the upstream floodplains making the atmosphere and leaf litter the primary inputs 508 to the system.

$509 \quad$ Floodplain fluxes of $\mathrm{CO}_{2}$ and $\mathrm{CH}_{4}$ can be approximated for four different floodplains that 510 represent the potential final condition of our conceptual model (Fig. 8e). All floodplains source $511 \mathrm{CO}_{2}$ to the atmosphere and have approximately the same magnitude of $\mathrm{CO}_{2}$ flux but the formerly 512 impounded floodplain has the lowest magnitude and the lowest variability, while the currently 
513 impounded floodplain has the largest variability and is the second largest magnitude of $\mathrm{CO}_{2}$ flux.

514 All of the floodplains are net sinks for $\mathrm{CH}_{4}$ with the impounded floodplain having the highest

515 variability of $\mathrm{CH}_{4}$ flux due to its time spent as a source of $\mathrm{CH}_{4}$ while inundated.

\section{$517 \quad$ 5. Conclusions}

Our ecogeomorphic study shows that run-of-river dams do not enhance floodplain

519 sedimentation, they promote periods of $\mathrm{CH}_{4}$ flux to the atmosphere, that the removal of a dam

520 will result in lower storage of total carbon and total nitrogen, and the removal of a dam may

521 facilitate the lateral erosion of up to $14 \mathrm{MgC}$. Run-of-river dam impacted floodplains receive

522 larger amounts of sediment during overbank events than unimpounded floodplains, and sand is

523 deposited across the entire. Impacted floodplains are also kept inundated for longer periods of

524 time, promoting $\mathrm{CH}_{4}$ flux during floodplain saturation. Yet despite periods of sourcing $\mathrm{CH}_{4}$ to

525 the atmosphere, all floodplains in our study were a net sink of $\mathrm{CH}_{4}$.

526 Sediment $\mathrm{CO}_{2}$ fluxes from the formerly impounded floodplain are of similar magnitude to

527 the other floodplains in our study, suggesting that any spike in $\mathrm{CO}_{2}$ flux from dam breaching is a

528 brief phenomenon related to multiple rewetting events (Kim et al 2012). Furthermore, spatial

529 heterogeneity in sediment $\mathrm{CO}_{2}$ fluxes should be considered, and continuous measurements are

530 needed to identify the exact timing and magnitude of a potential dam breaching pulse of $\mathrm{CO}_{2}$

531 flux (Vargas et al., 2011).

532 Despite all floodplains acting as sinks for $\mathrm{CH}_{4}$, it is important to recognize that recent

533 work has suggested that climate change may lead to potentially wetter conditions and more

534 frequent flood events (Bodelier et al., 2012; Perry et al., 2015). Extended wet periods combined

535 with more frequent flooding will likely yield longer periods of $\mathrm{CH}_{4}$ production from floodplains 
536 that are impounded by ROR dams. This could yield a potential positive feedback that could

537 convert impounded floodplains from sinks for $\mathrm{CH}_{4}$ to permanent sources of $\mathrm{CH}_{4}$, a process that

538 would have a global scale impact given the global abundance of ROR structures (Liu et al., 2014;

539 Vanmaercke et al., 2015).

540 


\section{Acknowledgements}

542 We would like to thank two anonymous reviewers who reviewed an earlier version of this

543 manuscript for their comments that helped improve the quality of the manuscript. Partial funding

544 was provided by the Department of Geological Sciences of the University of Delaware, NSF

545 grants EAR0724971 and EAR1331856, and USDA-AFRI grant 2013-02758. Field assistance

546 was provided by Tobias Ackerman, Meg Christie, Jeremey Keeler, Bridget O’Neil, Michael

547 Orefice, and Dale Lambert. 


\section{References}

550
Altor, A.E., Mitsch, W.J., 2006. Methane flux from created riparian marshes: Relationship to intermittent versus continuous inundation and emergent macrophytes. Ecol. Eng. 28, 224234. doi:10.1016/j.ecoleng.2006.06.006

Annandale, G.W., 2006. Reservoir Sedimentation, in: Encyclopedia of Hydrological Sciences. John Wiley \& Sons, Ltd. doi:10.1002/0470848944.hsa086

Batson, J., Noe, G.B., Hupp, C.R., Krauss, K.W., Rybicki, N.B., Schenk, E.R., 2014. Soil Greenhouse Gas Emissions and Carbon Budgeting in a Short-Hydroperiod Floodplain Wetland. J. Geophys. Res. Biogeosciences n/a-n/a. doi:10.1002/2014JG002817

Belger, L., Forsberg, B.R., Melack, J.M., 2010. Carbon dioxide and methane emissions from interfluvial wetlands in the upper Negro River basin, Brazil. Biogeochemistry 105, 171183. doi:10.1007/s10533-010-9536-0

Bodelier, P.L.E., Bär-Gilissen, M.-J., Meima-Franke, M., Hordijk, K., 2012. Structural and functional response of methane-consuming microbial communities to different flooding regimes in riparian soils. Ecol. Evol. 2, 106-27. doi:10.1002/ece3.34

Burke, R. a., Meyer, J.L., Cruse, J.M., Birkhead, K.M., Paul, M.J., 1999. Soil-atmosphere exchange of methane in adjacent cultivated and floodplain forest soils. J. Geophys. Res. 104, 8161. doi:10.1029/1999JD900015

Craft, C.B., Casey, W.P., 2000. Sediment and nutrient accumulation in floodplain and depressional freshwater wetlands of Georgia, USA. Wetlands 20, 323-332. doi:10.1672/0277-5212(2000)020[0323:SANAIF]2.0.CO;2

Csiki, S., Rhoads, B.L., 2010. Hydraulic and geomorphological effects of run-of-river dams. Prog. Phys. Geogr. 34, 755-780. doi:10.1177/0309133310369435

DeLaune, R.D., White, J.R., 2012. Will coastal wetlands continue to sequester carbon in response to an increase in global sea level?: A case study of the rapidly subsiding Mississippi river deltaic plain. Clim. Change 110, 297-314. doi:10.1007/s10584-011-00896

Delaware Department of Transportation, 2003. The Wooddale Bridge Replacement Project.

Donovan, M., Miller, A., Baker, M., Gellis, A., 2015. Sediment contributions from floodplains and legacy sediments to Piedmont streams of Baltimore County, Maryland. Geomorphology. doi:10.1016/j.geomorph.2015.01.025

Doyle, M.W., Stanley, E.H., Harbor, J.M., 2003a. Channel adjustments following two dam removals in Wisconsin. Water Resour. Res. 39, n/a-n/a. doi:10.1029/2002WR001714

Doyle, M.W., Stanley, E.H., Harbor, J.M., Grant, G.S., 2003b. Dam removal in the United States: Emerging needs for science and policy. Eos, Trans. Am. Geophys. Union 84, 29. doi:10.1029/2003EO040001

Fischer, J., Riva-Murray, K., Hickman, R.E., Chichester, D.C., Brightbill, R.A., Romanok, K.M., Bilger, M.D., 2004. Water Quality in the Delaware River Basin, Pennsylvania, New Jersey, New York and Delaware, 1999-2001, Circular 1. ed. U.S. Geological Survey, Reston, VA.

Fontaine, S., Bardoux, G., Benest, D., Verdier, B., Mariotti, A., Abbadie, L., 2004. Mechanisms 
of the Priming Effect in a Savannah Soil Amended with Cellulose. Soil Sci. Soc. Am. J. 68, 125. doi:10.2136/sssaj2004.0125

Galy-Lacaux, C., Delmas, R., 1997. Gaseous emissions and oxygen consumption in hydroelectric dams: A case study in French Guyana. Glob. ... 11, 471-483.

Gangloff, M.M., 2013. Taxonomic and ecological tradeoffs associated with small dam removals. Aquat. Conserv. Mar. Freshw. Ecosyst. 23, 475-480. doi:10.1002/aqc. 2383

Gartner, J.D., Magilligan, F.J., Renshaw, C.E., 2015. Predicting the Type, Location and Geomorphic Constraints. Geomorphology. doi:10.1016/j.geomorph.2015.02.023

Harris, N., Evans, J., 2014. Channel Evolution of Sandy Reservoir Sediments Following LowHead Dam Removal, Ottawa River, Northwestern Ohio, USA. Open J. Mod. Hydrol. 44-56.

Heimann, M., Reichstein, M., 2008. Terrestrial ecosystem carbon dynamics and climate feedbacks. Nature 451, 289-292. doi:10.1038/nature06591

Howard, A.D., 1998. Long profile development of bedrock channels: Interaction of weathering, mass wasting, bed erosion, and sediment transport. Rivers Over Rock Fluv. Process. Bedrock Channels. doi:10.1029/GM107p0297

Hupp, C., Noe, G., Schenk, E., Benthem, A., 2013. Recent and historic sediment dynamics along Difficult Run, a suburban Virginia Piedmont stream. Geomorphology.

Ishizuka, S., Sakata, T., Sawata, S., Ikeda, S., Sakai, H., Takenaka, C., Tamai, N., Onodera, S., Shimizu, T., Kan-na, K., Tanaka, N., Takahashi, M., 2009. Methane uptake rates in Japanese forest soils depend on the oxidation ability of topsoil, with a new estimate for global methane uptake in temperate forest. Biogeochemistry 92, 281-295. doi:10.1007/s10533-009-9293-0

Jacinthe, P. a., 2015. Carbon dioxide and methane fluxes in variably-flooded riparian forests. Geoderma 241-242, 41-50. doi:10.1016/j.geoderma.2014.10.013

Jacinthe, P. a., Vidon, P., Fisher, K., Liu, X., Baker, M.E., 2015. Soil Methane and Carbon Dioxide Fluxes from Cropland and Riparian Buffers in Different Hydrogeomorphic Settings. J. Environ. Qual. 0, 0. doi:10.2134/jeq2015.01.0014

Jacobson, R., Coleman, D., 1986. Stratigraphy and recent evolution of Maryland Piedmont flood plains. Am. J. Sci. 286, 617-637.

Juracek, K.E., 1999. Geomorphic effects of overflow dams on the lower Neosho River, Kansas. USGS Water Resour. Investig. Rep. 99-4147 2-7.

Kauffman, G., Belden, A., Homsey, A., Maxwell-doyle, M., Purdy, I., Fischer, J., Sherwin, L., 2008. State of the Delaware River Basin Report.

Kayranli, B., Scholz, M., Mustafa, A., Hedmark, Å., 2010. Carbon storage and fluxes within freshwater wetlands: A critical review. Wetlands 30, 111-124. doi:10.1007/s13157-0090003-4

Kim, D.G., Vargas, R., Bond-Lamberty, B., Turetsky, M.R., 2012. Effects of soil rewetting and thawing on soil gas fluxes: A review of current literature and suggestions for future research. Biogeosciences 9, 2459-2483. doi:10.5194/bg-9-2459-2012

Li, G., Wang, X.T., Yang, Z., Mao, C., West, a. J., Ji, J., 2014. Dam-triggered organic carbon 
sequestration makes the Changjiang (Yangtze) river basin (China) a significant carbon sink. J. Geophys. Res. Biogeosciences n/a-n/a. doi:10.1002/2014JG002646

Liu, Y., Yang, W., Yu, Z., Lung, I., Yarotski, J., Elliott, J., Tiessen, K., 2014. Assessing the effects of small dams on stream flow and water quality in an agricultural watershed. J. Hydrol. Eng. 140402181753009. doi:10.1061/(ASCE)HE.1943-5584.0001005

Lyons, N.J., Starek, M.J., Wegmann, K.W., Mitasova, H., 2015. Bank erosion of legacy sediment at the transition from vertical to lateral stream incision. Earth Surf. Process. Landforms n/a-n/a. doi:10.1002/esp.3753

Major, J., O’Connor, J., Podolak, C., 2012. Geomorphic response of the Sandy River, Oregon, to removal of Marmot Dam.

Merritts, D., Walter, R., Rahnis, M., Hartranft, J., Cox, S., Gellis, A., Potter, N., Hilgartner, W., Langland, M., Manion, L., Lippincott, C., Siddiqui, S., Rehman, Z., Scheid, C., Kratz, L., Shilling, A., Jenschke, M., Datin, K., Cranmer, E., Reed, A., Matuszewski, D., Voli, M., Ohlson, E., Neugebauer, A., Ahamed, A., Neal, C., Winter, A., Becker, S., 2011. Anthropocene streams and base-level controls from historic dams in the unglaciated midAtlantic region, USA. Philos. Trans. A. Math. Phys. Eng. Sci. 369, 976-1009. doi:10.1098/rsta.2010.0335

Mitsch, W.J., Zhang, L., Fink, D.F., Hernandez, M.E., Altor, A.E., Tuttle, C.L., Nahlik, A.M., 2008. Ecological engineering of floodplains. Ecohydrol. Hydrobiol. 8, 139-147. doi:10.2478/v10104-009-0010-3

Nanson, G.C., Croke, J.C., 1992. A genetic classification of floodplains. Geomorphology 4, 459486.

Orr, C.H., Roth, B.M., Forshay, K.J., Gonzales, J.D., Papenfus, M.M., Wassell, R.D.G., 2004. Examination of Physical and Regulatory Variables Leading to Small Dam Removal in Wisconsin. Environ. Manage. 33, 99-109. doi:10.1007/s00267-003-2941-6

Pacific, V.J., McGlynn, B.L., Riveros-Iregui, D. a., Epstein, H.E., Welsch, D.L., 2009. Differential soil respiration responses to changing hydrologic regimes. Water Resour. Res. 45, W07201. doi:10.1029/2009WR007721

Parekh, P., Mccully, P., 2004. A Preliminary Review of the Impact of Dam Reservoirs on Carbon Cycling. Change 1-8.

Pearson, A.J., Pizzuto, J., 2015. Bedload transport over run-of-river dams, Delaware, U.S.A. Geomorphology. doi:10.1016/j.geomorph.2015.07.025

Pearson, A.J., Snyder, N.P., Collins, M.J., 2011. Rates and processes of channel response to dam removal with a sand-filled impoundment. Water Resour. Res. 47, n/a-n/a. doi:10.1029/2010WR009733

Perry, L.G., Reynolds, L. V., Beechie, T.J., Collins, M.J., Shafroth, P.B., 2015. Incorporating climate change projections into riparian restoration planning and design. Ecohydrology $\mathrm{n} / \mathrm{a}-$ n/a. doi:10.1002/eco.1645

Pizzuto, J., 2002. Effects of Dam Removal on River Form and Process. Bioscience 52, 683. doi:10.1641/0006-3568(2002)052[0683:EODROR]2.0.CO;2

Pizzuto, J.E., Moody, J. a., Meade, R.H., 2008. Anatomy and Dynamics of a Floodplain, Powder 
Pumpanen, J., Kolari, P., Ilvesniemi, H., Minkkinen, K., Vesala, T., Niinistö, S., Lohila, A., Larmola, T., Morero, M., Pihlatie, M., Janssens, I., Yuste, J.C., Grünzweig, J.M., Reth, S., Subke, J.A., Savage, K., Kutsch, W., Østreng, G., Ziegler, W., Anthoni, P., Lindroth, A., Hari, P., 2004. Comparison of different chamber techniques for measuring soil CO 2 efflux. Agric. For. Meteorol. 123, 159-176. doi:10.1016/j.agrformet.2003.12.001

Qiao, N., Schaefer, D., Blagodatskaya, E., Zou, X., Xu, X., Kuzyakov, Y., 2014. Labile carbon retention compensates for $\mathrm{CO} 2$ released by priming in forest soils. Glob. Chang. Biol. 20, 1943-1954. doi:10.1111/gcb.12458

Renner, G.T., 1927. The Physiographic Interpretation of the Fall Line. Geogr. Rev. 17, $278-286$.

Rosa, L., Santos, M. Dos, Matvienko, B., 2004. Greenhouse gas emissions from hydroelectric reservoirs in tropical regions. Clim. Change 9-21.

Sawaske, S.R., Freyberg, D.L., 2012. A comparison of past small dam removals in highly sediment-impacted systems in the U.S. Geomorphology 151-152, 50-58. doi:10.1016/j.geomorph.2012.01.013

Schenck, W.S., Plank, M.O., Srogi, L., 2000. Bedrock geologic map of the Piedmont of Delaware and adjacent Pennsylvania.

Schenk, E.R., Hupp, C.R., 2009. Legacy Effects of Colonial Millponds on Floodplain Sedimentation, Bank Erosion, and Channel Morphology, Mid-Atlantic, USA. JAWRA J. Am. Water Resour. Assoc. 45, 597-606. doi:10.1111/j.1752-1688.2009.00308.x

Segers, R., 1998. Methane production and methane consumption: a review of processes underlying wetland methane fluxes. Biogeochemistry 23-51.

Senior, L. a, Koerkle, E.H., Report, W.I., Groat, C.G., 2003. Simulation of Streamflow and Water Quality in the Christina River Subbasin and Overview of Simulations in Other Subbasins of the Christina River Basin , Pennsylvania , Maryland , and Delaware , 1994-98.

Sha, C., Mitsch, W.J., Mander, Ü., Lu, J., Batson, J., Zhang, L., He, W., 2011. Methane emissions from freshwater riverine wetlands. Ecol. Eng. 37, 16-24. doi:10.1016/j.ecoleng.2010.07.022

Skalak, K., Pizzuto, J., Egan, J., Allmendinger, N., 2011. The geomorphic effects of existing dams and historic dam removals in the U.S. Mid-Atlantic region, in: Sediment Dynamics upon Dam Removal.

Skalak, K.J., Benthem, A.J., Schenk, E.R., Hupp, C.R., Galloway, J.M., Nustad, R. a., Wiche, G.J., 2013. Large dams and alluvial rivers in the Anthropocene: The impacts of the Garrison and Oahe Dams on the Upper Missouri River. Anthropocene 2, 51-64. doi:10.1016/j.ancene.2013.10.002

Stanley, E., Doyle, M., 2003. Trading off: the ecological effects of dam removal. Front. Ecol. Environ. 3220.

State of Delaware, O., 2008. New Castle County contours. Dover, DE.

Teodoru, C.R., Bastien, J., Bonneville, M.-C., del Giorgio, P. a., Demarty, M., Garneau, M., Hélie, J.-F., Pelletier, L., Prairie, Y.T., Roulet, N.T., Strachan, I.B., Tremblay, A., 2012. The net carbon footprint of a newly created boreal hydroelectric reservoir. Global 
Biogeochem. Cycles 26, n/a-n/a. doi:10.1029/2011GB004187

713 Tullos, D.D., Finn, D.S., Walter, C., 2014. Geomorphic and ecological disturbance and recovery 714 from two small dams and their removal. PLoS One 9, e108091.

715 doi:10.1371/journal.pone.0108091

716 Turowski, J.M., Hovius, N., Wilson, A., Horng, M.-J., 2008. Hydraulic geometry, river sediment

717

718 and the definition of bedrock channels. Geomorphology 99, 26-38. doi:10.1016/j.geomorph.2007.10.001

Vanmaercke, M., Poesen, J., Govers, G., Verstraeten, G., 2015. Quantifying human impacts on catchment sediment yield: A continental approach. Glob. Planet. Change. doi:10.1016/j.gloplacha.2015.04.001

Vargas, R., Carbone, M.S., Reichstein, M., Baldocchi, D.D., 2011. Frontiers and challenges in soil respiration research: from measurements to model-data integration. Biogeochemistry 102, 1-13. doi:10.1007/s10533-010-9462-1

Vargas, R., Collins, S.L., Thomey, M.L., Johnson, J.E., Brown, R.F., Natvig, D.O., Friggens, M.T., 2012. Precipitation variability and fire influence the temporal dynamics of soil CO 2 efflux in an arid grassland. Global Change Bio. 18, 1401-1411. doi:10.1111/j.13652486.2011.02628.x

Walter, R.C., Merritts, D.J., 2008. Natural streams and the legacy of water-powered mills. Science 319, 299-304. doi:10.1126/science.1151716

Wang, Y., Chen, L., Gao, Y., Wang, S., Lü, Y., Fu, B., 2014. Carbon Sequestration Function of Check-Dams: A Case Study of the Loess Plateau in China. Ambio. doi:10.1007/s13280014-0518-7

Wentworth, C.K., 1922. A Scale of Grade and Class Terms for Clastic Sediments. J. Geol. 30, 377-392. doi:10.1086/622910 
Table 1. Sediment depths, cross sectional widths and mass of carbon stored of each floodplain at the Barley Mill Road (BMR; currently impounded) and Fell Spice Mill (FSM; formerly

741 impounded) sites.

\begin{tabular}{|c|c|c|c|c|c|c|}
\hline & \multicolumn{3}{|c|}{ Upstream BMR } & \multicolumn{3}{|c|}{ Downstream BMR } \\
\hline & $\mathrm{XS}+3$ & $\mathrm{XS}+4$ & $\mathrm{XS}+5$ & XS-1 & XS-2 & XS-3 \\
\hline $\begin{array}{l}\text { Near floodplain depth } \\
\text { (m) }\end{array}$ & 3.035 & 3.02 & 2.99 & 2.15 & 2.03 & 1.91 \\
\hline $\begin{array}{l}\text { Middle floodplain depth } \\
\text { (m) }\end{array}$ & 1.88 & 1.83 & 2.11 & 2.16 & 1.97 & 1.74 \\
\hline $\begin{array}{l}\text { Far floodplain depth } \\
\text { (m) }\end{array}$ & 0.89 & 1.61 & 1.54 & 2.04 & 1.86 & 1.54 \\
\hline $\begin{array}{l}\text { Average depth } \\
\text { (m) }\end{array}$ & 1.94 & 2.15 & 2.21 & 2.12 & 1.95 & 1.73 \\
\hline $\begin{array}{l}\text { Floodplain width } \\
\text { (m) }\end{array}$ & 21.4 & 33.2 & 43 & 32.2 & 42.5 & 37.8 \\
\hline $\begin{array}{c}\text { Floodplain average depth } \\
(\mathbf{m})\end{array}$ & \multicolumn{3}{|c|}{$2.10 \pm 0.76$} & \multicolumn{3}{|c|}{$1.93 \pm 0.20$} \\
\hline $\begin{array}{l}\text { Floodplain average width } \\
(\mathbf{m})\end{array}$ & \multicolumn{3}{|c|}{$32.5 \pm 10.8$} & \multicolumn{3}{|c|}{$37.5 \pm 5.16$} \\
\hline $\begin{array}{l}\text { Mass of Carbon } \\
(\mathrm{MgC})\end{array}$ & \multicolumn{3}{|c|}{$80 \pm 41$} & \multicolumn{3}{|c|}{$58 \pm 8.4$} \\
\hline & \multicolumn{3}{|c|}{ Upstream FSM } & \multicolumn{3}{|c|}{ Downstream FSM } \\
\hline & $\mathrm{XS}+3$ & $\mathrm{XS}+2$ & $X S+1$ & XS-1 & XS-2 & XS-3 \\
\hline $\begin{array}{l}\text { Near floodplain depth } \\
\text { (m) }\end{array}$ & 1.99 & 2.64 & 2.11 & 0.65 & 0.98 & 0.46 \\
\hline $\begin{array}{l}\text { Middle floodplain depth } \\
(\mathrm{m})\end{array}$ & 1.41 & 1.17 & 0.93 & 1.15 & 1.22 & 1.21 \\
\hline $\begin{array}{l}\text { Far floodplain depth } \\
(\mathrm{m})\end{array}$ & 0.64 & 0.65 & 0.90 & 1.29 & 1.28 & 1.18 \\
\hline $\begin{array}{l}\text { Average depth } \\
\text { (m) }\end{array}$ & 1.35 & 1.49 & 1.31 & 1.03 & 1.16 & 0.95 \\
\hline $\begin{array}{l}\text { Floodplain width } \\
\text { (m) }\end{array}$ & 34.7 & 22.7 & 19.4 & 15.8 & 22 & 14.3 \\
\hline $\begin{array}{l}\text { Floodplain average depth } \\
\text { (m) }\end{array}$ & \multicolumn{3}{|c|}{$1.38 \pm 0.71$} & \multicolumn{3}{|c|}{$1.05 \pm 0.30$} \\
\hline $\begin{array}{l}\text { Floodplain average width } \\
\text { (m) }\end{array}$ & \multicolumn{3}{|c|}{$25.6 \pm 8.05$} & \multicolumn{3}{|c|}{$17.4 \pm 4.08$} \\
\hline $\begin{array}{c}\text { Mass of Carbon } \\
(\mathrm{MgC})\end{array}$ & \multicolumn{3}{|c|}{$66 \pm 40$} & \multicolumn{3}{|c|}{$17 \pm 6.8$} \\
\hline
\end{tabular}




\section{$744 \quad$ Figure legends}

745 Fig. 1. Study area map for the field experiment. A) Overview of the length of stream studied,

746 including United States Geologic Survey (USGS) gaging station (yellow circle) and Mt. Cuba

747 weather station (star). Barley Mill Road Site, the currently impounded site, is shown in the upper

748 panel and the upstream (B) and downstream (C) floodplains are shown with near, middle and far

749 floodplain locations delineated as well as the sampling locations on the cross sections. Fell Spice

750 Mill site, the formerly impounded site, is shown in the bottom panel and also has the upstream

751 (D) and downstream (E) floodplains with delineated near, middle and far floodplain regions as

752 well as the sampling locations.

753

754 Fig. 2.Total nitrogen and total carbon data at depth for the Barley Mill Road site. (A) Percent

755 total nitrogen of $20 \mathrm{mg}$ samples with multiple samples from similar depths averaged together.

756 (B) Percent total carbon of $20 \mathrm{mg}$ samples with multiple samples from similar depths averaged

757 together. (C) Mass of nitrogen per area of depth, and (D) mass of carbon per area of depth for

758 BMR site with multiple samples from similar depths are averaged together to plot one line for

759 upstream floodplain and one line for downstream floodplain. Upstream data are represented by

760 black squares and downstream data are represented by gray squares. Points that had multiple

761 samples at the same depth also have their standard deviation shown.

762

763 Fig. 3.Total nitrogen and total carbon data at depth for the Fell Spice Mill site. (A) Percent total

764 nitrogen of $20 \mathrm{mg}$ samples with multiple samples from similar depths averaged together. (B)

765 Percent total carbon of $20 \mathrm{mg}$ samples with multiple samples from similar depths averaged

766 together. (C) Mass of nitrogen per area of depth, and (D) mass of carbon per area of depth for 
767 FSM site with multiple samples from similar depths are averaged together to plot one line for

768 upstream floodplain and one line for downstream floodplain. Upstream data are represented by

769 black circles and downstream data are represented by gray circles.Points that had multiple

770 samples at the same depth also have their standard deviation shown.

771

772 Fig. 4.Hyetograph for Red Clay Creek study area from March 1, 2014 to December 31, 2014

773

774 Fig. 5. Temporal and spatial patterns related to $\mathrm{CO}_{2}$ flux, $\mathrm{CH}_{4}$ flux, sediment temperature, and 775 sediment moisture.

777 Fig. 6.Sediment temperature and sediment moisture plotted again $\mathrm{CO}_{2}$ and $\mathrm{CH}_{4}$ flux for Barley

778 Mill Road and Fell Spice Mill sites. Significant regressions and $r^{2}$ values are shown for

779 significant trends $(\mathrm{p}<0.05)$

780

781 Fig.7. Averaged biomass data for the four floodplains based on floodplain location and total

782 average for each floodplain. Letters indicate if the different floodplain locations are statistically

783 different. Columns with matching letters indicate no statistically significant difference whereas

784 columns with differing letters indicate a statistically significant difference between locations on 785 the floodplain in question.

786

787 Fig. 8.Conceptual model of the influence of run-of-river dams on floodplain construction and 788 carbon cycling based on stages of damming. A) Initial building of the dam and accretion of the 789 upstream floodplain. B) Upstream floodplain is elevated above stream. After elevation of 
790 floodplain there are two options that can happen to a dam: C) option 1 continued damming or D)

791 option 2 dam removal/breaching. E) Approximate flux magnitude, direction, and variability for

792 each of the four distinct floodplain ecosystems. Note: $\mathrm{OM}=$ organic matter addition, $\mathrm{sed}=$

793 sediment addition, and arrows show magnitude of process relative to the other processes

794

795 
796

797
Figure 1

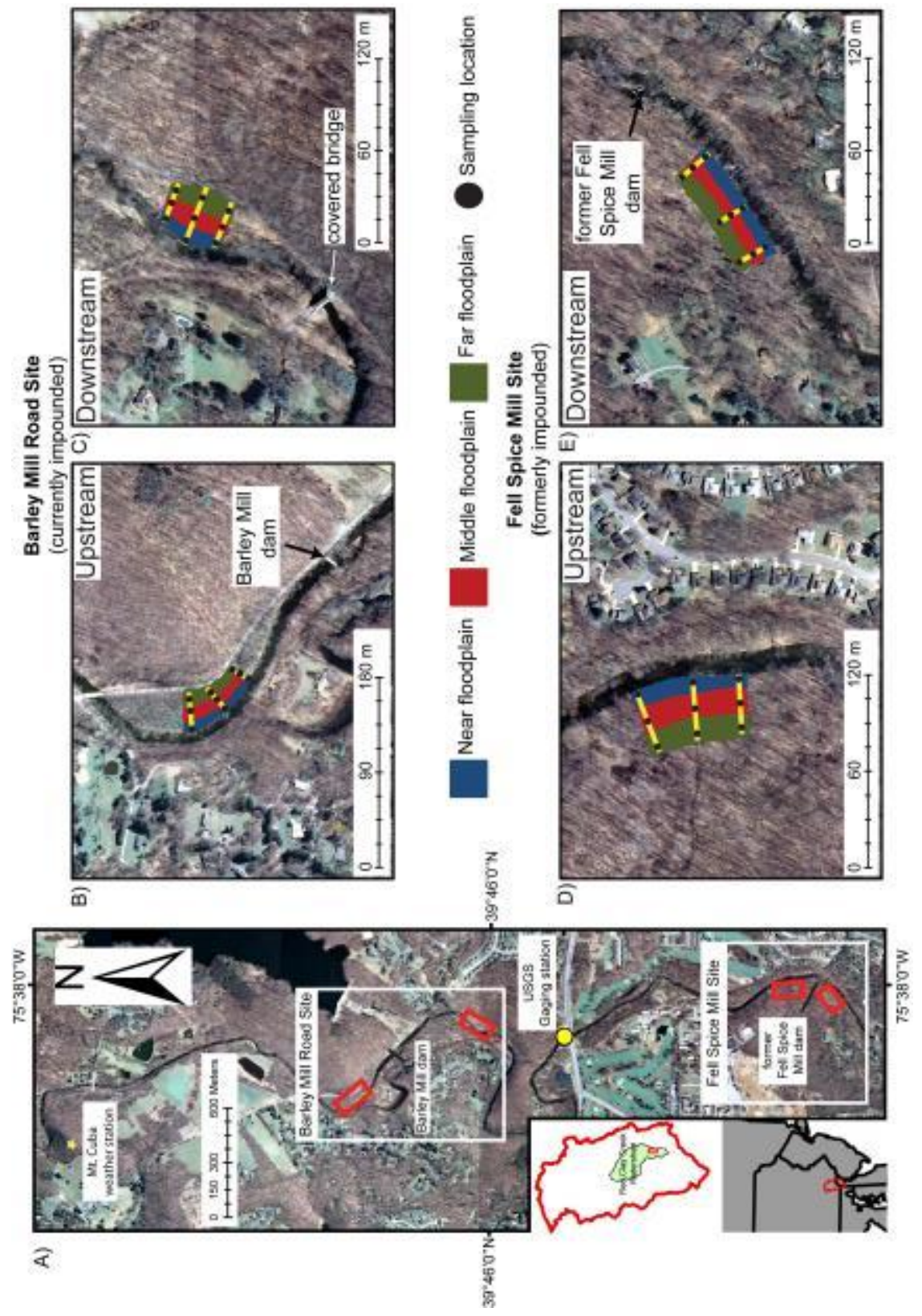


$801 \quad$ Figure 2

802

(A) Total nitrogen (\%)

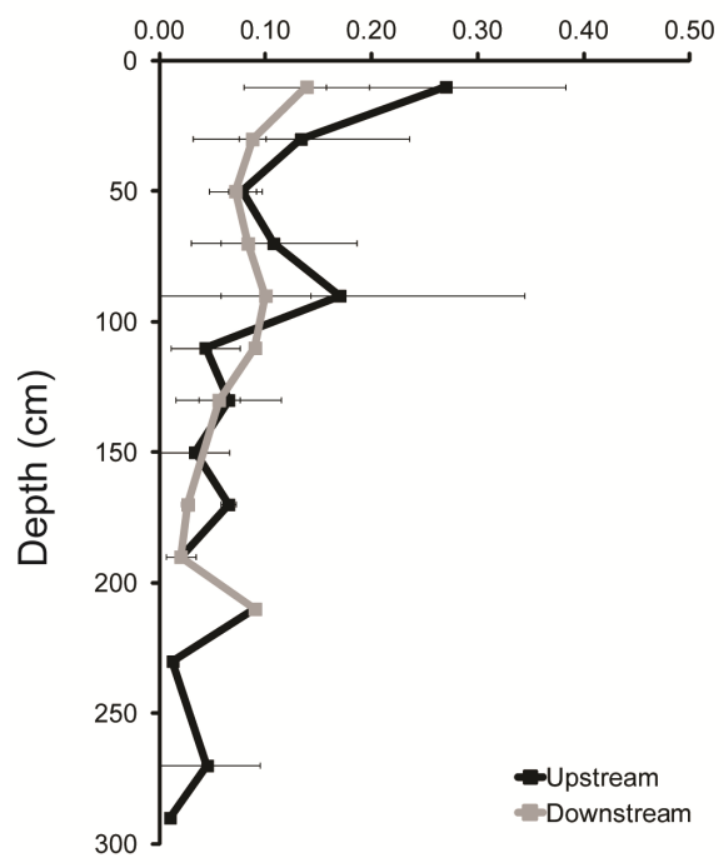

(C)

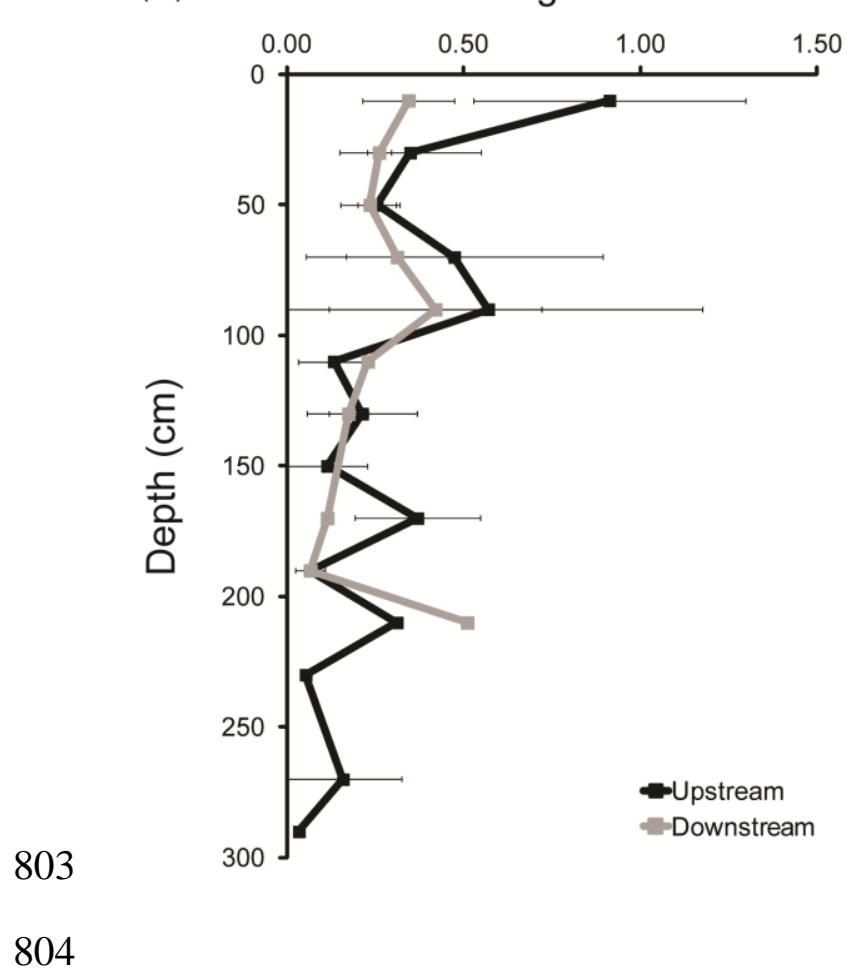

(B)

Total carbon (\%)

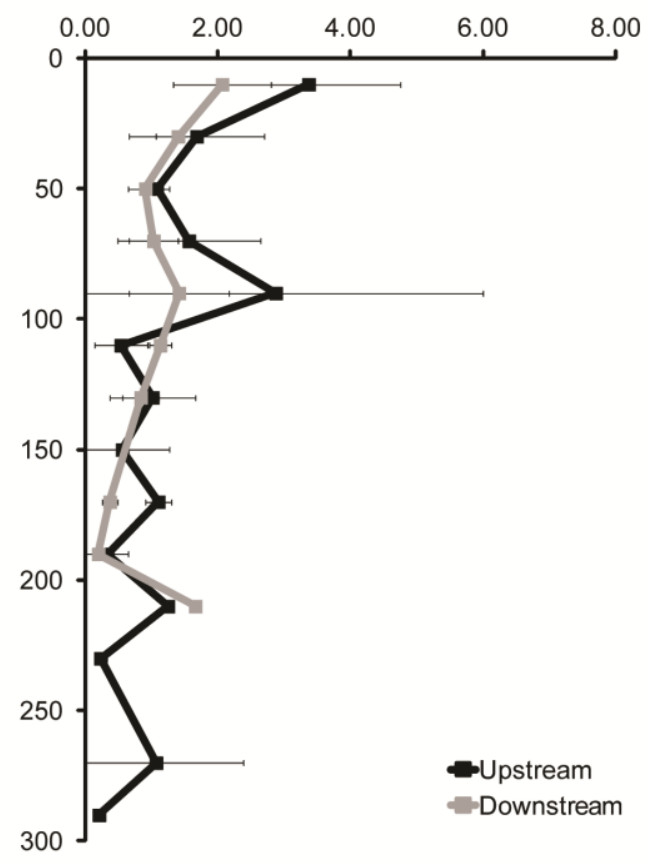

(D)

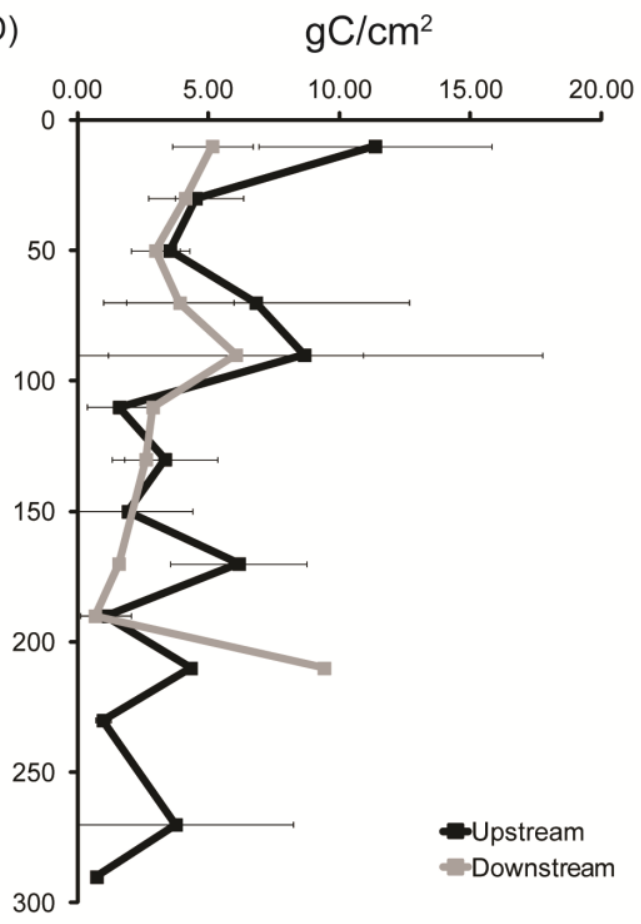


Figure 3

806

(A) Total nitrogen (\%)

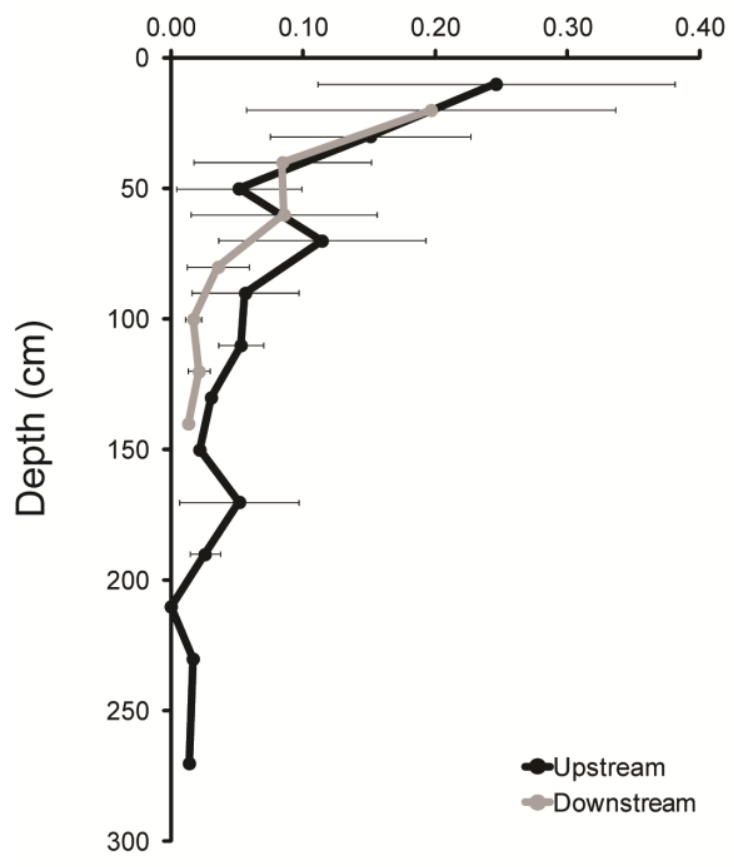

(C)

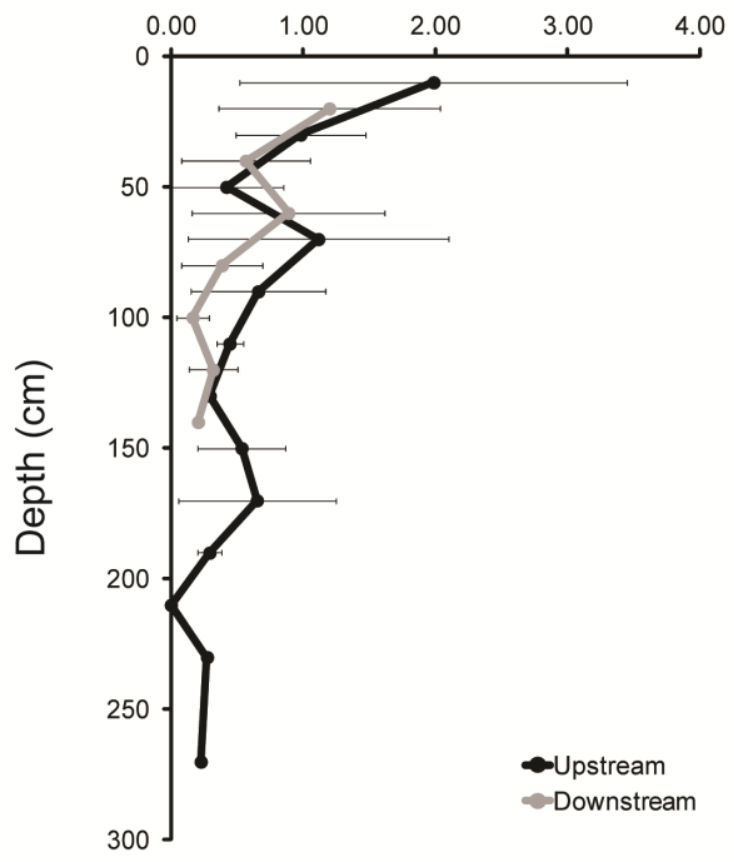

(B) Total carbon (\%)

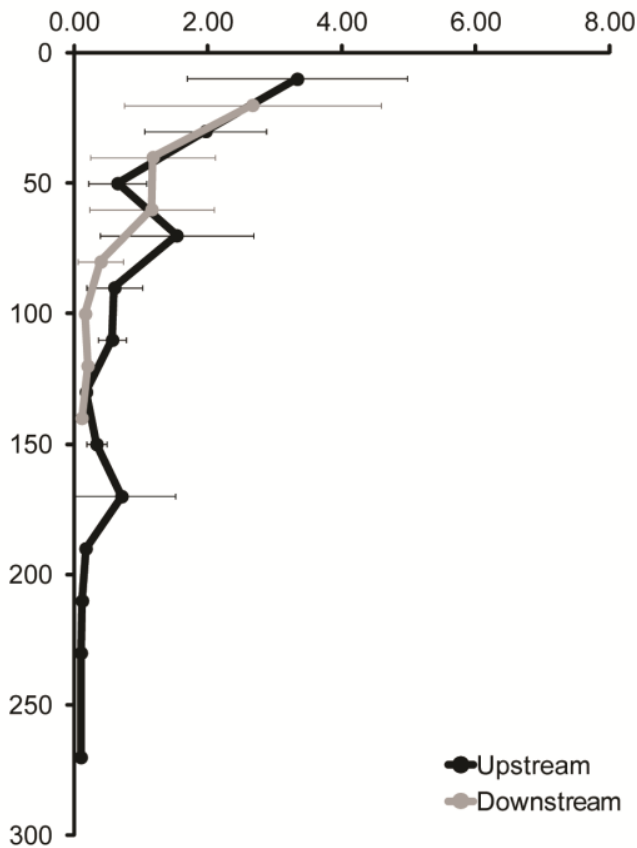

(D) $\mathrm{gC} / \mathrm{cm}^{2}$

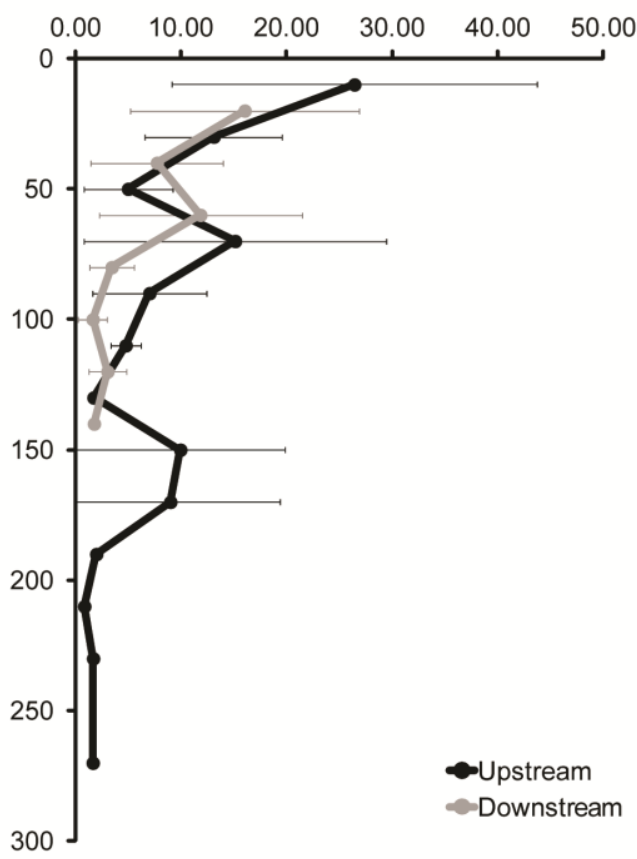


811 Figure 4

812

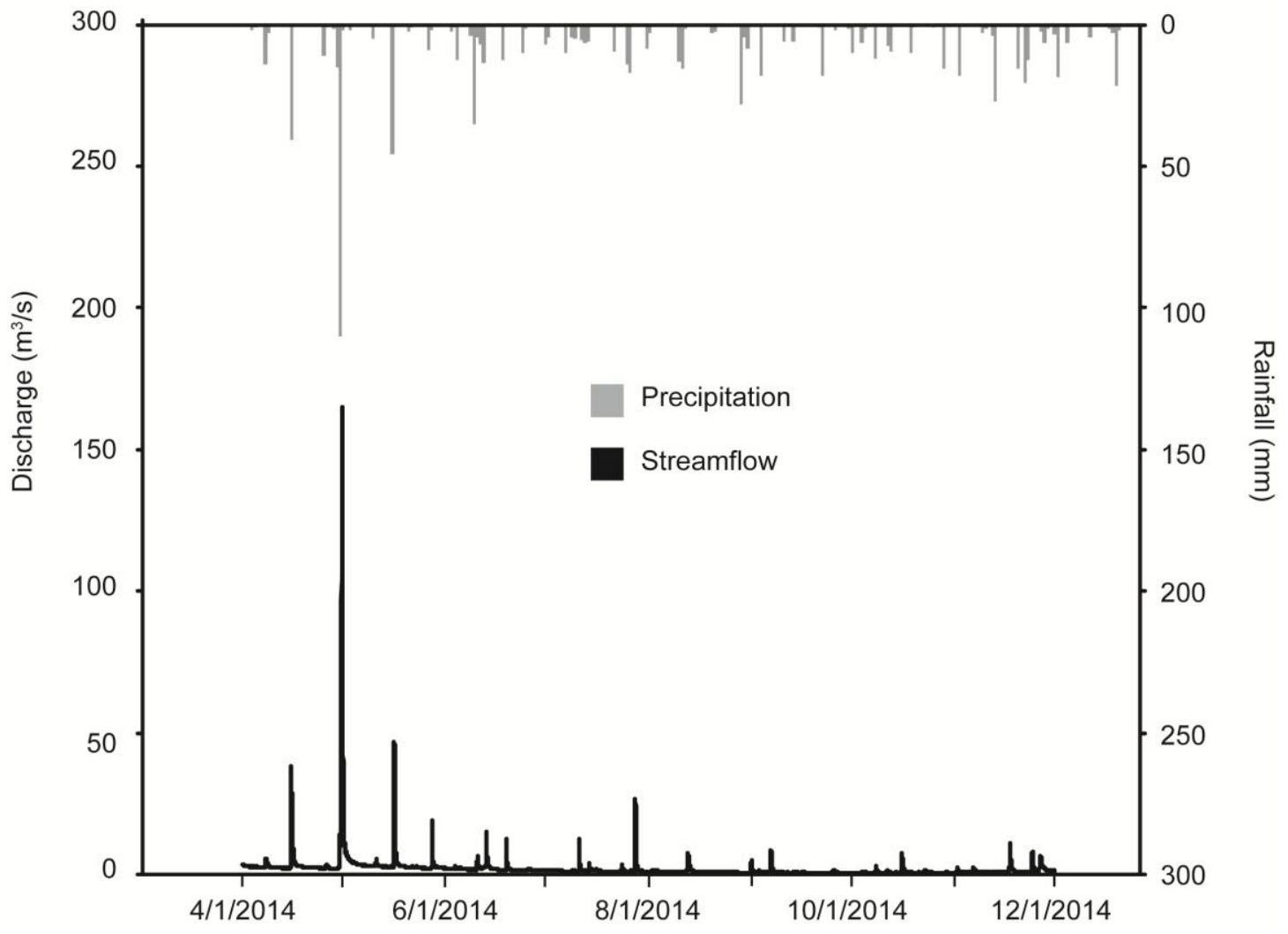

814

815 
Figure 5

817
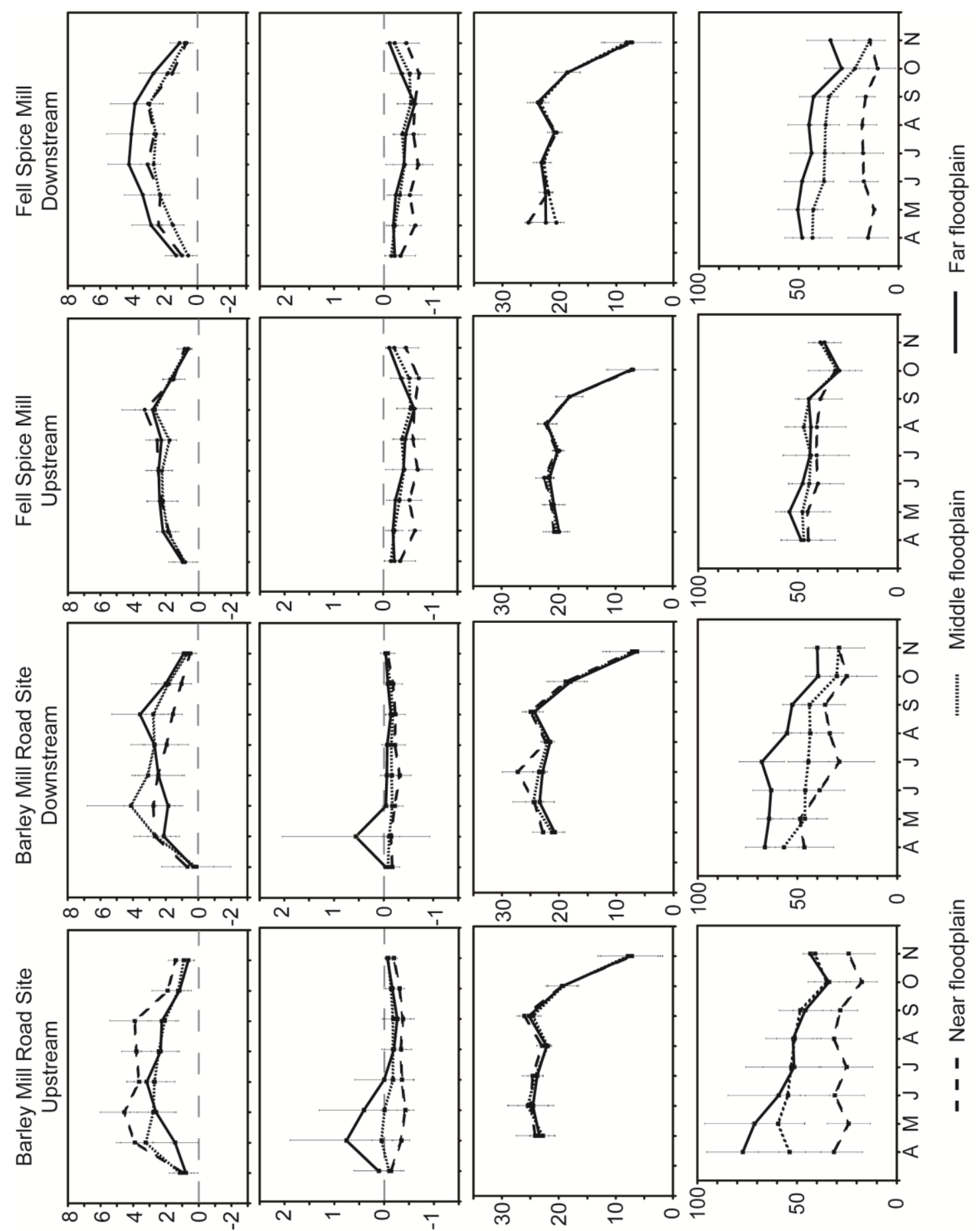

(1.- ${ }^{2}-\mathrm{m}$ ourr)

$\mathrm{xn|y}^{2} \mathrm{O}$

(

xn! ${ }^{\circ} \mathrm{HO}$
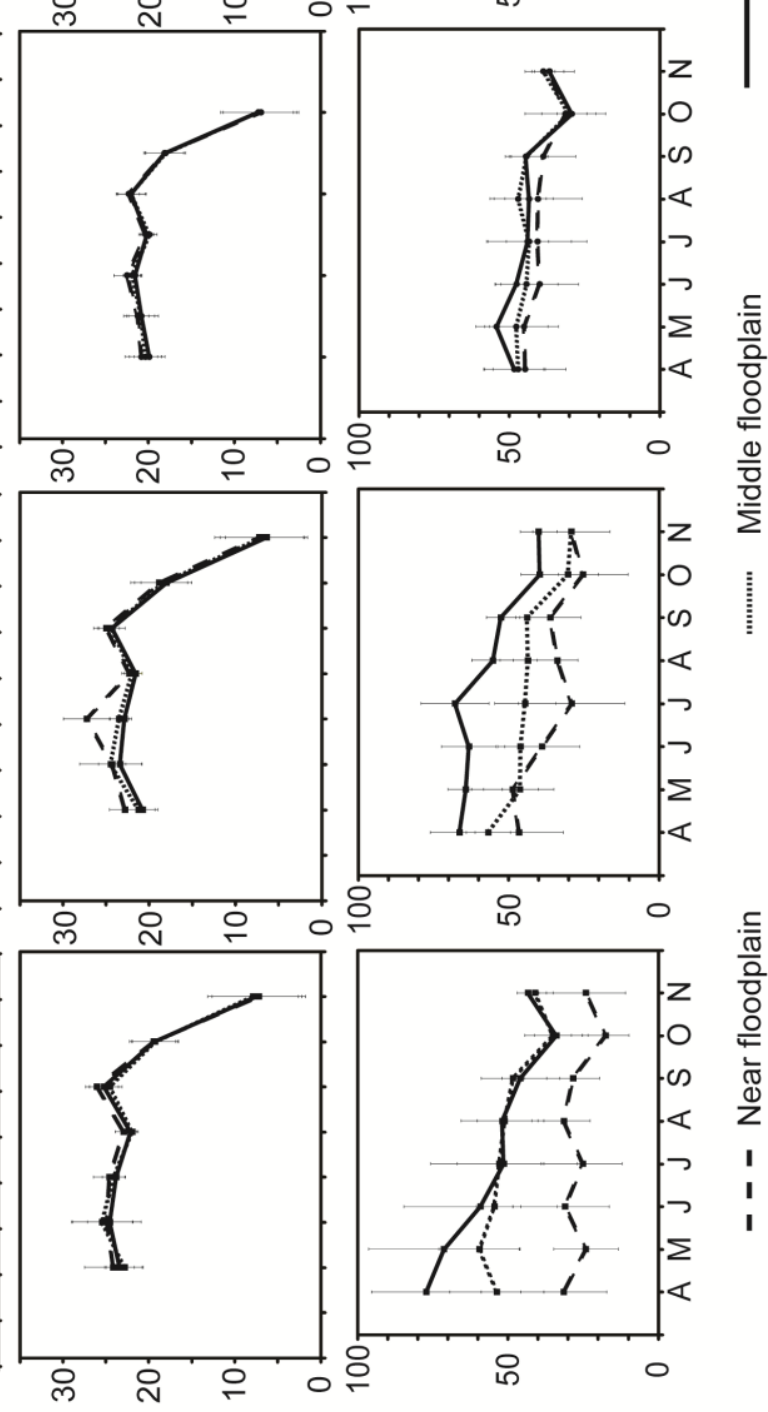

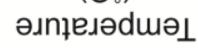

(\%)

$\theta$ 
Figure 6

Barley Mill Road Site
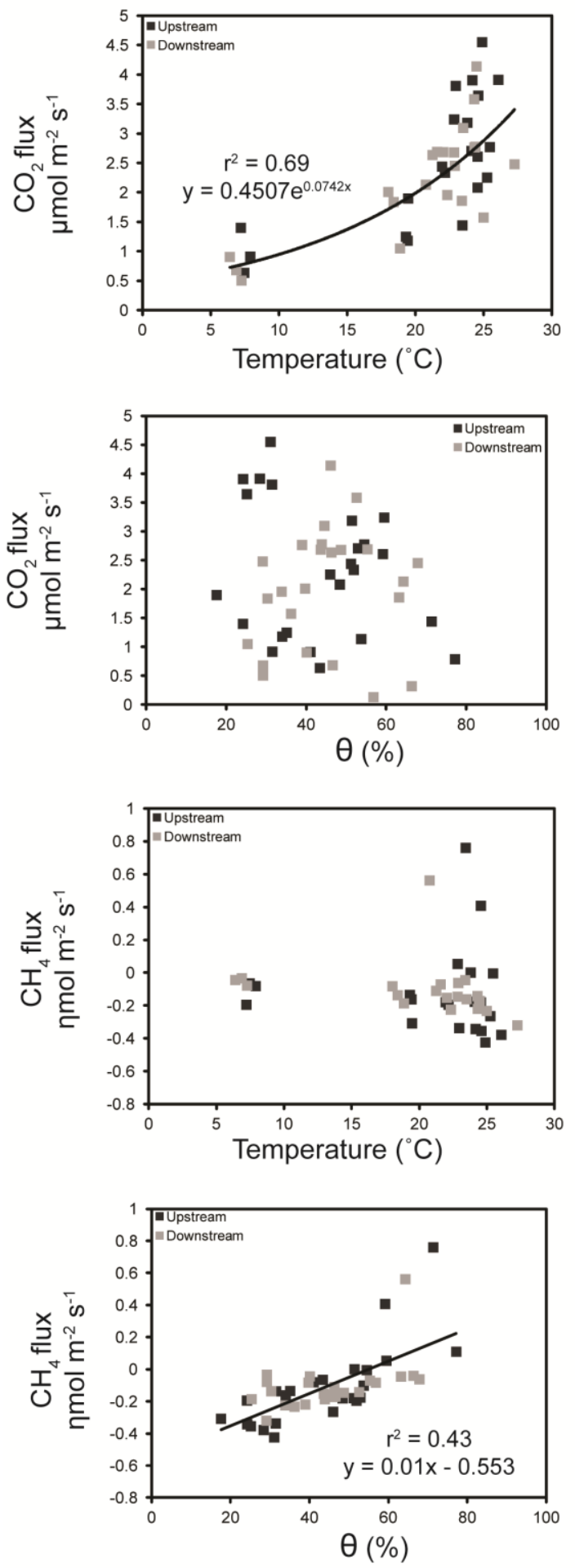

Fell Spice Mill Site
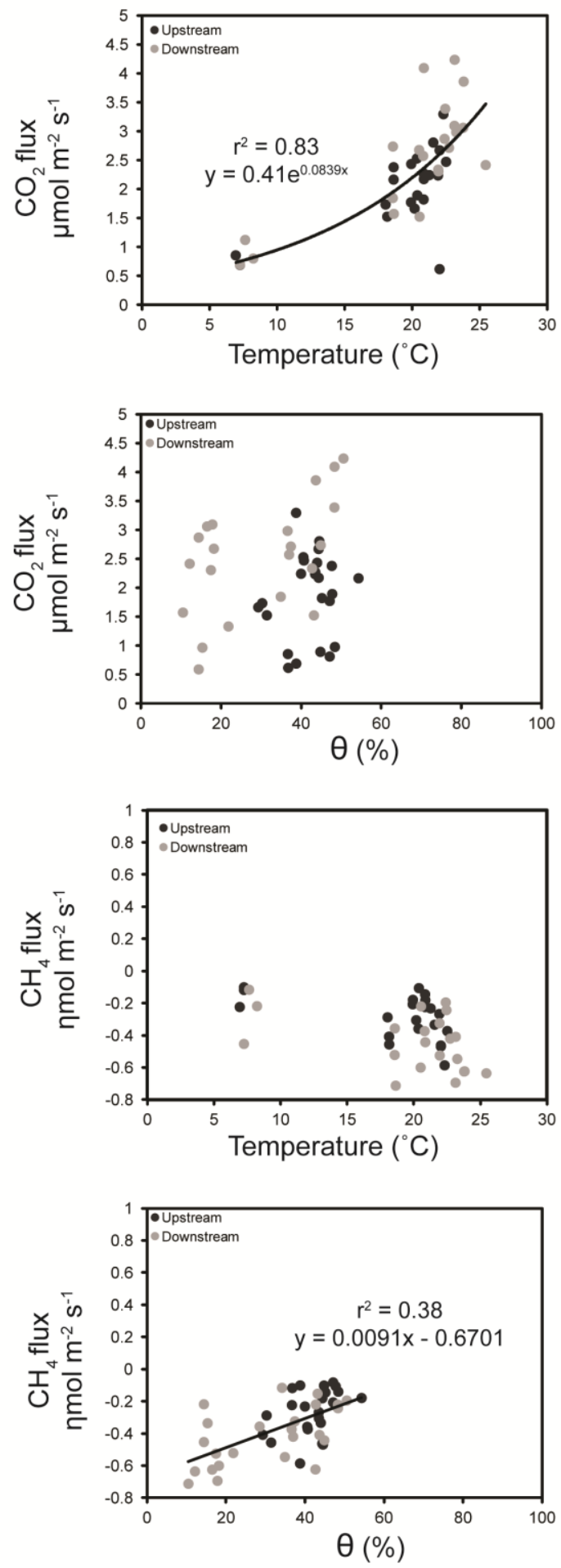
(A)

Barley Mill Road Site
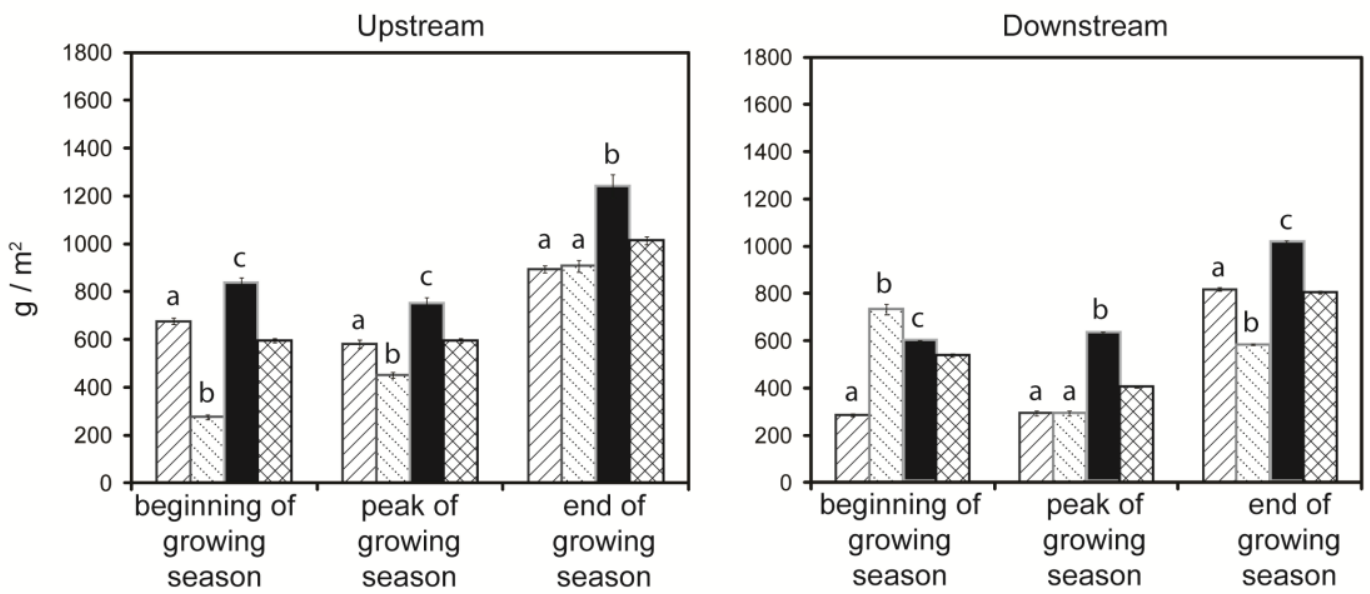

(B)

Fell Spice Mill Site
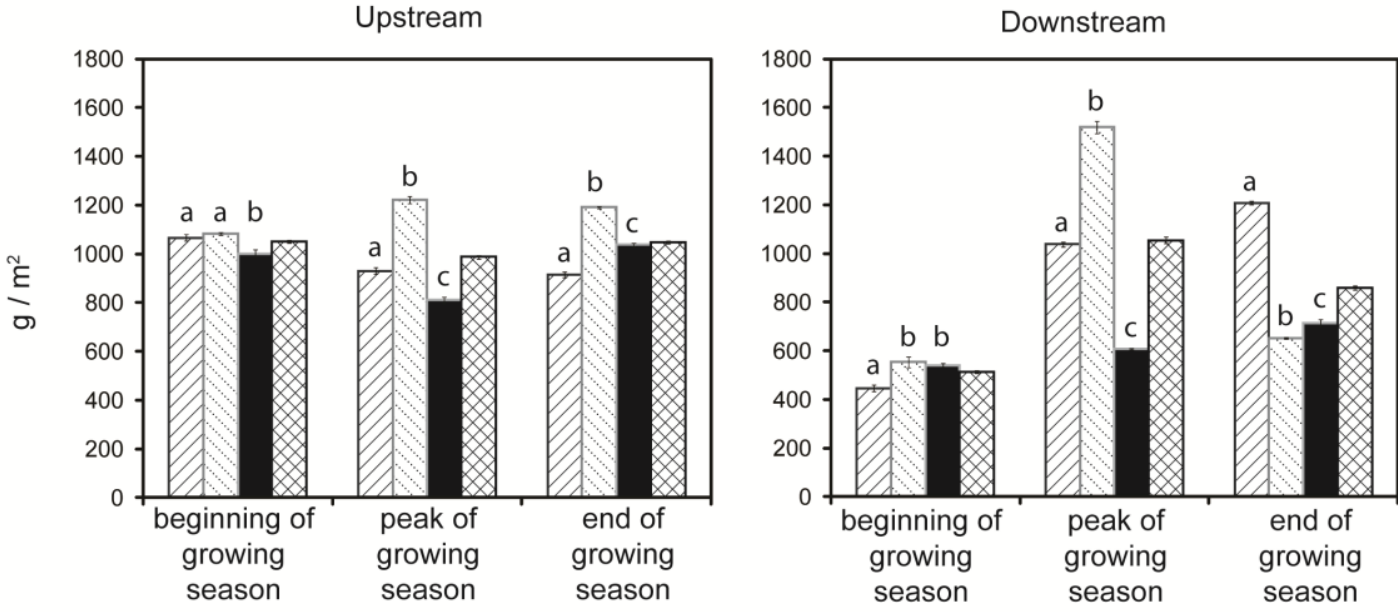

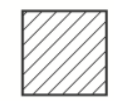

Near floodplain

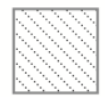

Middle floodplain

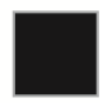

Far floodplain

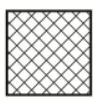

Total average 
Figure 8

830

831

A) Dam construction and floodplain accretion

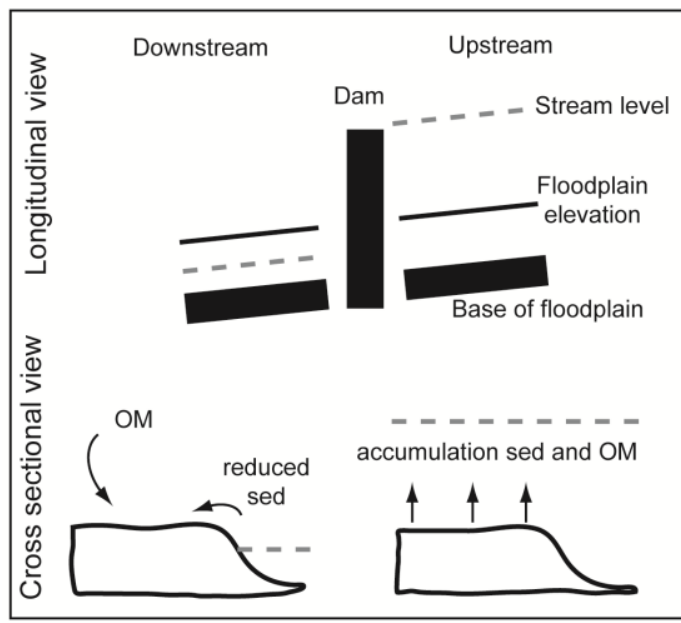

C) Option 1: Continued Damming

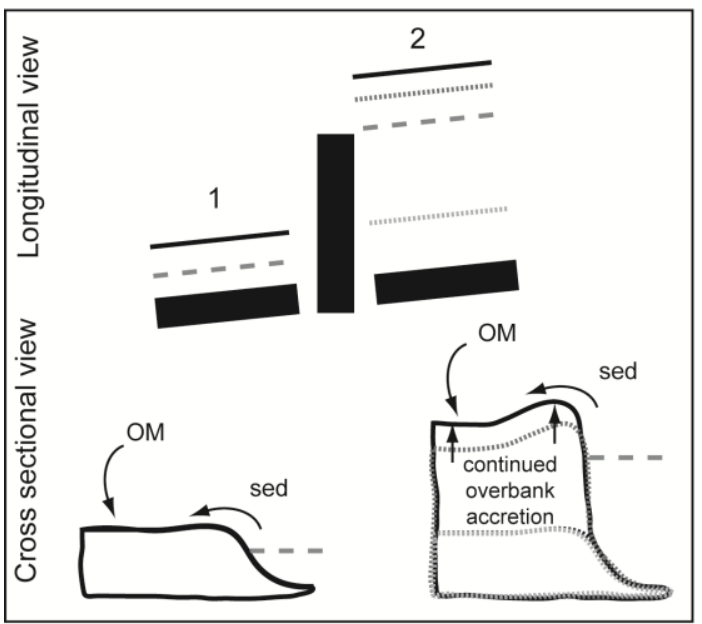

B) Elevated impounded floodplain

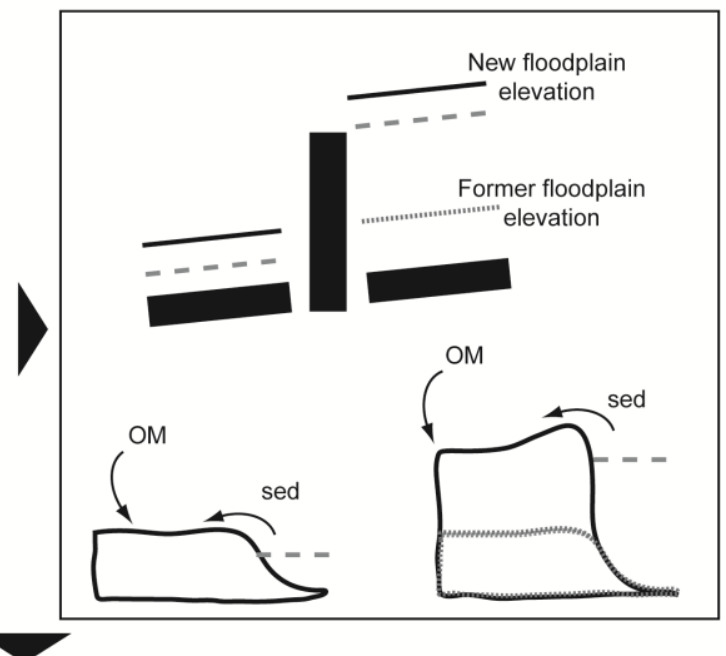

D) Option 2: Dam removed

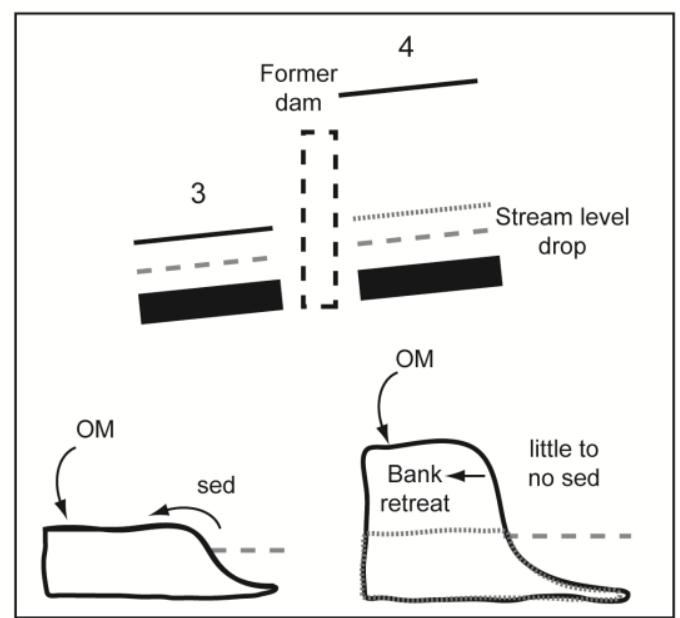

E) Approximate soil gas flux magnitude, direction and standard deviation of floodplains from panel C and D

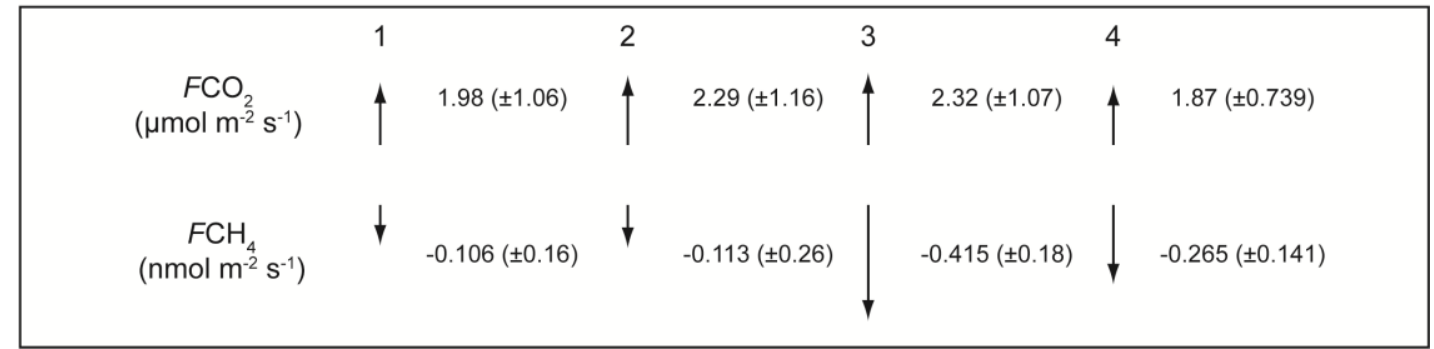

